\title{
Communities and change in the anthropocene: understanding social-ecological vulnerability and planning adaptations to multiple interacting exposures
}

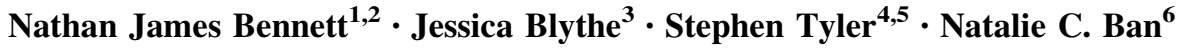

Received: 26 January 2015/Accepted: 4 July 2015/Published online: 4 August 2015

(c) The Author(s) 2015. This article is published with open access at Springerlink.com

\begin{abstract}
The majority of vulnerability and adaptation scholarship, policies and programs focus exclusively on climate change or global environmental change. Yet, individuals, communities and sectors experience a broad array of multi-scalar and multi-temporal, social, political, economic and environmental changes to which they are vulnerable and must adapt. While extensive theoreticaland increasingly empirical-work suggests the need to explore multiple exposures, a clear conceptual framework which would facilitate analysis of vulnerability and adaptation to multiple interacting socioeconomic and biophysical changes is lacking. This review and synthesis paper aims to fill this gap through presenting a conceptual framework for integrating multiple exposures into vulnerability analysis and adaptation planning. To support applications of the framework and facilitate assessments and comparative analyses of community vulnerability, we
\end{abstract}

Editor: Jamie Pittock.

Nathan James Bennett

nathan.bennett@ubc.ca;

http://nathanbennett.ca

1 Institute for Resources, Environment and Sustainability, University of British Columbia, 2202 Main Mall, Vancouver, BC V6T 1Z4, Canada

2 School of Marine and Environmental Affairs, University of Washington, Seattle, WA, USA

3 ARC Centre of Excellence for Coral Reef Studies and WorldFish, James Cook University, Townsville, Australia

4 Adaptive Resource Management, Victoria, BC, Canada

5 Department of Geography, University of Victoria, Victoria, BC, Canada

6 School of Environmental Studies, University of Victoria, Victoria, BC, Canada develop a comprehensive typology of drivers and exposures experienced by coastal communities. Our results reveal essential elements of a pragmatic approach for localscale vulnerability analysis and for planning appropriate adaptations within the context of multiple interacting exposures. We also identify methodologies for characterizing exposures and impacts, exploring interactions and identifying and prioritizing responses. This review focuses on coastal communities; however, we believe the framework, typology and approach will be useful for understanding vulnerability and planning adaptation to multiple exposures in various social-ecological contexts.

Keywords Social-ecological systems · Vulnerability . Adaptation · Exposure - Adaptive capacity · Coastal communities - Drivers of change

The complexity, unpredictability and pace of events in our world, and the severity of global environmental stress, are soaring....Many societies, groups, and people adapt reasonably well to our swiftly changing world, but others have fallen behind and risk being overwhelmed by converging pressures. Thomas Homer-Dixon, The Ingenuity Gap, 2000.

\section{Introduction}

"Change is the only constant...", Heraclitus might have been talking about communities when he said this in ancient Greece. For contemporary communities around the world, each situated in a distinct social-ecological context and each with their own histories and visions for the future, anthropogenic change is occurring with increasing rapidity, complexity and uncontrollability (IPCC 2014; Steffen et al. 
2015). The drivers of these changes occur at different scales and speeds and include environmental, climatic, economic, technological, sociocultural, demographic and governance factors (Millenium Ecosystem Assessment 2005; Zou and Wei 2010; Bennett et al. 2014b). Communities are exposed to these exogenous changes through direct and indirect impacts on the interrelated components of social-ecological systems (Turner et al. 2003; Perry et al. 2010). Multiple socioeconomic and biophysical changes occurring simultaneously at different scales and speeds interact to produce drastically different outcomes for communities in different places (O'Brien and Leichenko 2003; O'Brien et al. 2004; Tuler et al. 2008; Brklacich et al. 2009). Yet, the predominant focus of vulnerability and adaptation research, policy and practice has been solely on climate change or global environmental change. This focus on a single driver of change is often the result of a problem-centered, rather than community-centered, approach.

Understanding the multiple, interacting drivers and impacts of these changes on social-ecological systems is paramount for ecological sustainability and for human wellbeing. Authors from various disciplines, including socialecological systems and resilience (Berkes et al. 2003; Turner et al. 2003; Walker et al. 2004), sustainable livelihoods (Ellis 2000; Scoones 2009), hazards research (Berkes 2007; Smith 2013), fisheries (Tuler et al. 2008; Perry et al. 2010; Kittinger et al. 2013), agriculture (Eakin 2005; Paavola 2008) and climate change vulnerability and adaptation (Adger 2006; Marshall et al. 2010; Eriksen et al. 2011; Roiko et al. 2012), have stressed the importance of considering multiple interacting exposures in research, policy and practice. Initially, this discussion remained largely at the conceptual realm (Turner et al. 2003; Brklacich et al. 2009). A limited but increasing body of empirical work explores the nature of drivers and exposures, and the interactions between exposures as experienced by local groups and communities (O'Brien and Leichenko 2000; Bunce et al. 2010b; Bennett et al. 2014b). Yet, in many cases the bottomup approaches taken in empirical studies have led to results that: (a) fail to explore the breadth of changes to which communities are exposed and (b) inadequately examine how these changes interact to produce variable outcomes for linked social and environmental assets that are important to local communities. Indeed, few case studies of coastal vulnerability are guided by conceptual frameworks, which have led to limited comparability among sites, countries and regions (Zou and Wei 2010). Typically, these conceptual and empirical approaches simplify the scope of changes to which communities are exposed, invariably leading to onedimensional adaptation policies, programs and actions that fail to address the multifaceted and multi-scalar drivers of change, and the complexity and uncertainty of changes in local social-ecological systems.
No single conceptual framework synthesizes the broad range of theoretical advancements on multiple exposures. Deliberate progress toward the goal of long-term sustainability requires an understanding of the dynamics of multiple drivers of change, and resulting exposures, impacts and responses, in linked social-ecological systems. In this article, we review and synthesize the existing theoretical and empirical work on drivers of change in coastal socialecological systems to: (a) present a conceptual framework for understanding vulnerability to multiple interacting exposures, (b) develop a comprehensive typology of drivers, exposures and impacts being experienced by coastal communities, (c) propose essential elements of a pragmatic approach for vulnerability analysis and adaptation planning and (d) explore methods for assessing the impacts of, and responses to, multiple exposures in coastal social-ecological systems. To limit the scope of the paper, this review focuses on coastal communities, which face both land- and sea-based exposures. However, we believe the framework, typology and approach can be applied to understand socialecological change and to develop appropriate response strategies in various contexts.

\section{Vulnerability to multiple exposures: key concepts and conceptual framework}

The concept of vulnerability is rooted primarily in scholarship on development and livelihoods (Sen 1982; Chambers and Conway 1992; Scoones 1998), hazards (Burton et al. 1993; Watts and Bohle 1993; Mustafa 1998), global environmental change (Vogel 1998; Turner et al. 2003; Smit and Wandel 2006) and resilience (Holling 2001; Gunderson and Pritchard 2002; Folke et al. 2003). There have been several dominant ways of conceptualizing vulnerability (Adger 2006). The first is to view vulnerability as an outcome through focusing on the impacts of a hazard, such as climate change, and the ability of a system to respond. The purpose of "end point" vulnerability analysis is to estimate and reduce costs of hazards. A second perspective emphasizes vulnerability as the "starting point" and focuses on the historical factors or current characteristics of individuals, households, communities, sectors, nations, etc. that determine their differential susceptibility to harm. A more comprehensive view considers vulnerability to be the result of the interaction between exposure, sensitivity and adaptive capacity (Turner et al. 2003; Smit and Wandel 2006; Perry et al. 2010). Exposure refers to the degree to which trends and shocks, driven by changes at various scales, are experienced by a region, resource or group. Sensitivity is the susceptibility of an entity or system to the effects of an exposure. Historical, social, political, economic and environmental preconditions determine a system's sensitivity. 
Watts and Bohle (1993) suggest resource distribution, political power and voice, rights, and access to institutions mediate sensitivity. Exposure and sensitivity combined define the potential impacts of a change. Impacts can be unevenly experienced by various similarly exposed groups (genders, ages, classes, racial groups, livelihoods, etc.) based on differential sensitivities (O'Brien and Leichenko 2000). Adaptive capacity refers to "the ability to respond to challenges through learning, managing risk and impacts, developing new knowledge and devising effective approaches" (Marshall et al. 2010). Adaptive capacity is latent potential until it is applied in response to a change. Adaptive capacity is determined by access to assets (human, social, physical, financial and natural), capacity to organize, leadership, learning and knowledge, imaginative resources and capacity to self-organize (Folke et al. 2003; Cinner et al. 2009; Bussey et al. 2012; Bennett et al. 2014a). In this view of vulnerability, the relationship between the three components of vulnerability might be simplified to an equation: $V=E+S-\mathrm{AC}$ - whereby vulnerability $(V)$ is determined by exposure $(E)$ plus sensitivity $(S)$ minus adaptive capacity (AC) (Adger 2006).

We next introduce seven key considerations that should shape analysis of vulnerability and responses to help maintain a resilient system. We integrate these elements into a conceptual framework for understanding community socialecological vulnerability (Fig. 1). First, while many analyses of vulnerability focus on impacts and outcomes in either social or ecological subsystems, we argue that either focus is incomplete. Relevant systems for vulnerability analysis must address linked social and ecological components (Turner et al. 2003; Brklacich et al. 2009). Social-ecological systems can be defined as complex, integrative and adaptive systems, wherein humans are part of nature (Berkes and Folke 1998). Even in urban areas, ecosystems are important elements of resilience (Tyler and Moench 2012).

Second, large-scale exogenous conditions and trends that operate at different scales and speeds (defined as "drivers") drive local exposures (Armitage and Johnson 2006; Perry et al. 2010). More rigorous understandings of multi-scalar drivers will lead to insights into exposures and responses (Hall 2011; Kittinger et al. 2013). Drivers of change can be biophysical-i.e., climate change and other environmental changes-and socioeconomic-i.e., economic transformation, technological change, sociocultural evolution, demographic change and shifts in governance structures and institutions.

Third, exposures have often been framed as being affected by stressors, risks or hazards that lead to harms (Sen 1982; Burton et al. 1993; Watts and Bohle 1993; Berkes 2007). Yet, local exposure to trends and shocks does not necessarily lead to negative outcomes for all social or ecological components of systems. Exposures can also be experienced as opportunities for reorganization and renewal and may lead to either desirable or undesirable outcomes (Holling 2001; Gunderson and Pritchard 2002).

Fourth, better incorporation of multiple exposures into analysis of vulnerability will lead to more effective vulnerability research and adaptation policy (Leichenko and O'Brien 2008; Brklacich et al. 2009; Bunce et al. 2010a; Smith et al. 2013; Bennett et al. 2014b). Many vulnerability assessments rely on large-scale and top-down studies using predetermined indicators that make implicit assumptions about the nature of changes being experienced. More empirical studies are needed to ground theoretical work in the complexities of local experiences of multiple exposures (Turner et al. 2003; Silva et al. 2010; Zou and Wei 2010) and to better identify actions to improve institutions and policies (Hall 2011).

Fifth, many analyses of vulnerability, resilience and adaptive capacity are static snapshots of the present that do not account adequately for interactions and feedbacks. Systems are dynamic with constantly changing drivers, exposures, impacts, responses and outcomes. Impacts can be direct or interactive. Interactive impacts result from interactions between drivers at higher scales, cascading effects of direct impacts from exposures, autonomous feedbacks between and among social and ecological components, and the feedbacks of adaptive responses to direct impacts. For example, Friedman (2013) suggests that climate change can be a "scary hidden stressor" as distant communities might indirectly experience rises in the price of a staple food as a result of the impacts of climate change elsewhere, leading to political unrest. Cinner et al. (2011) argue that it is critical to understand whether adaptive responses lead to amplifying or dampening feedbacks. Amplifying feedbacks are those that increase vulnerability or erode social-ecological resilience over the longer term, whereas dampening feedbacks reduce the impact of negative trends. Outcomes slide back and forth on a continuum between vulnerability to sustainability for both social and ecological criteria and change over time.

Sixth, responses to exposures can be characterized as coping or adapting (Smit and Wandel 2006; Bennett et al. 2014a). Coping refers to short-term reactive or unplanned responses to moderate the impacts of, or reduce sensitivity to, exposures. Sometimes, coping strategies can be maladaptive and increase overall sensitivity and vulnerability in the longer term. For example, intensification of fishing effort is a short-term strategy often employed by fishers that will lead to longer-term reductions in fish productivity and abundance. Adapting refers to proactive planning of longer-term courses of action that lead to beneficial outcomes for social and ecological systems. Adaptations fall within three categories: (a) preventive actions to reduce exposure and sensitivity, (b) strengthening adaptive 


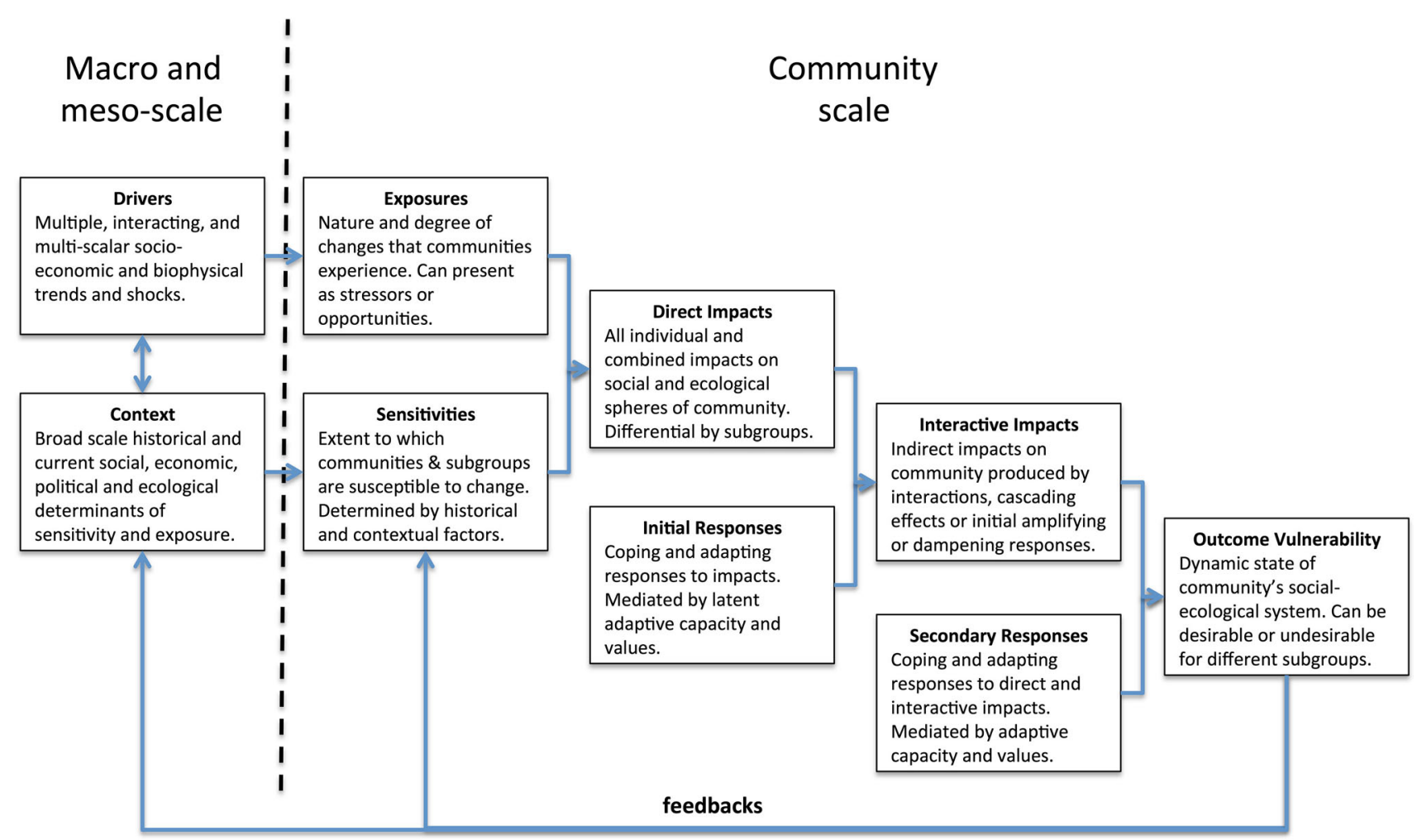

Fig. 1 Conceptual framework for understanding community social-ecological vulnerability to multiple interacting exposures

capacity and (c) measures that improve social and ecological outcomes (Smit and Wandel 2006). Adaptive strategies reduce exposure and sensitivity over the long term and thereby reduce system vulnerability.

Finally, adaptation options are limited by institutional and material constraints as well as social structures and governance processes, culture and values (Adger et al. 2009a; O'Brien 2009; Adger et al. 2009b, 2013; ElrickBarr et al. 2014; IPCC 2014). Values mediate perceptions of risk, determine desired outcomes or goals and influence courses of action or adaptations (Hicks and Cinner 2014). O'Brien and Wolf (2010) argue "...what is considered as effective and legitimate adaptation depends on what people perceive to be worth preserving and achieving. How to adapt to climate change therefore hinges on the values underlying people's perspectives on what the goals of adaptation should be." Adaptation decision-making processes should make explicit and incorporate diverse values as well as feasibility and constraints.

The aforementioned considerations are incorporated into a conceptual framework for understanding and analyzing local community vulnerability to multiple exposures (Fig. 1) which builds on work by others (Turner et al. 2003; Smit and Wandel 2006; Perry et al. 2010). The framework shows vulnerability as a dynamic process and outcome of socialecological systems that results from exposure to multi-scalar and dynamic drivers, contextualized and differential sensitivities, direct and interactive impacts. Responses to perceived vulnerability include multiple coping and adapting measures mediated by adaptive capacity and values. Values define what are considered desirable or undesirable outcomes for social or ecological spheres of a community system.

\section{Typology of drivers, exposures, impacts and interactions in coastal communities}

This section reviews and categorizes drivers, exposures and impacts experienced by coastal communities (Table 1). The typology is separated into biophysical and socioeconomic drivers and exposures. Interactions within and between the two spheres are also discussed.

\section{Bio-physical drivers, exposures and impacts}

\section{Climate change related}

Between 1955 and 2010, the temperature of top 700 meters of the planet's oceans increased by an average of $0.18^{\circ} \mathrm{C}$, with direct impacts on marine life and the human communities that rely on marine resources (Bunce et al. 2010b; Levitus et al. 2012). One consequence of warming water is 
the reduction in sea ice. In Alaska, earlier spring ice break-up is limiting spring fishing (a critical source of protein following the winter), while unpredictable ice conditions hinder winter travel and access to marine resources (Moerlein and Carothers 2012). As a result of the decline of polar ice sheet mass, global mean sea level has risen by 0.19 meters during the last century and could potentially surpass a $1-\mathrm{m}$ rise by 2100 (Pfeffer et al. 2008; Church and White 2011). Sea level rise will have profound impacts on coastal ecosystems, such as a projected loss of 10-20\% of global mangroves by 2100 (McGranahan et al. 2007). Moreover, sea level rise poses serious socioeconomic risk since $10 \%$ of the world's population lives in low-elevation $(<10 \mathrm{~m})$ coastal zones (Nicholls et al. 2007). Climate change is increasing the frequency and magnitude of extreme weather events such as tropical storms, which threaten coastal infrastructure and exacerbate dangers fishers face at sea (Knutson et al. 2010; Blythe et al. 2013). The warming of the upper layers of the ocean is driving greater stratification of the water column, changes in ocean circulation and variable precipitation patterns, all of which will perpetuate significant change in coastal systems.

Climate change is also generating profound changes in chemical ocean properties. Since the industrial revolution, global oceans have absorbed 25 percent of anthropogenic carbon dioxide (Le Quéré et al. 2012). As a result of this uptake, the average $\mathrm{pH}$ of ocean surface waters has fallen from 8.2 to 8.1 in a process known as ocean acidification (Feely et al. 2009). While this decrease appears relatively small, a decrease of $0.3-0.4 \mathrm{pH}$ units by the end of this century would represent the oceans' lowest $\mathrm{pH}$ value in 40 million years (Pelejero et al. 2010). Organisms that use carbonate ions dissolved in sea water to form shells or skeletal structures, such as plankton, benthic molluscs, echinoderms and corals, may be negatively impacted by lower ocean $\mathrm{pH}$, although species' sensitivity will vary (Doney et al. 2009; Kroeker et al. 2010). Since many of these organisms form the foundation of marine trophic chains, ocean acidification may have large ecological and social consequences (Fabricius et al. 2011; Busch et al. 2013). Oceanic dissolved oxygen has also decreased since 1960, albeit with strong regional variations (Keeling et al. 2010). Decreased dissolved $\mathrm{O}_{2}$ has widespread implications for ocean productivity, nutrient cycling, carbon cycling and marine habitats.

The changes in the physical and chemical conditions of the world's oceans have prompted a wide range of ecological responses. Increasing evidence suggests that many reef fish species are already living close to their thermal optima (Rummer et al. 2014), meaning that that higher ocean temperatures will lead to reduced fitness or mortality (Munday et al. 2008). Many marine species, ranging from turtles to phytoplankton, have altered their distributions in response to warming waters in order to maintain their optimal thermal range (Polovina et al. 2008; Pike 2014). These relocations

Table 1 Typology of biophysical and socioeconomic drivers and exposures

\begin{tabular}{|c|c|c|c|}
\hline \multicolumn{2}{|c|}{ Drivers of change } & \multicolumn{2}{|l|}{ Exposures } \\
\hline Classification & Subclassification & Categories of exposure & Types of exposure \\
\hline \multirow[t]{18}{*}{ Biophysical } & \multirow[t]{12}{*}{ Climate change } & \multirow[t]{6}{*}{ Physical properties } & Changing oceanic temperature \\
\hline & & & Reduced sea ice \\
\hline & & & Sea level rise \\
\hline & & & Extreme weather events and storm surges \\
\hline & & & Variable precipitation patterns \\
\hline & & & Changing atmospheric temperature \\
\hline & & \multirow[t]{2}{*}{ Chemical properties } & Ocean acidification \\
\hline & & & Reduced dissolved oxygen \\
\hline & & \multirow[t]{4}{*}{ Ecological responses } & Species range shifts \\
\hline & & & Reduced thermal optima \\
\hline & & & Coral bleaching \\
\hline & & & Ecosystem changes, invasive species, diseases and biodiversity loss \\
\hline & \multirow[t]{6}{*}{ Other Environmental } & \multirow[t]{2}{*}{ Ocean-based } & Overfishing \\
\hline & & & Habitat degradation \\
\hline & & Hazards & Earthquakes, tsunamis, fires, floods \\
\hline & & \multirow[t]{3}{*}{ Land-based } & Nutrient loading \\
\hline & & & Fresh water use \\
\hline & & & Pollution and garbage \\
\hline
\end{tabular}


Table 1 continued

\begin{tabular}{|c|c|c|c|}
\hline \multicolumn{2}{|c|}{ Drivers of change } & \multicolumn{2}{|l|}{ Exposures } \\
\hline Classification & Subclassification & Categories of exposure & Types of exposure \\
\hline \multirow[t]{14}{*}{ Socioeconomic } & Demographic & Population & $\begin{array}{l}\text { Urbanization/gentrification } \\
\text { Changing age/sex distribution }\end{array}$ \\
\hline & & Migration & $\begin{array}{l}\text { In-migration from other regions or countries } \\
\text { Permanent or temporary out-migration }\end{array}$ \\
\hline & & Health & $\begin{array}{l}\text { Chronic illness or acute diseases } \\
\text { Injuries and disabilities } \\
\text { Mental, emotional and spiritual health }\end{array}$ \\
\hline & Economic & $\begin{array}{l}\text { Macroscale economic } \\
\text { institutions and } \\
\text { processes }\end{array}$ & $\begin{array}{l}\text { Economic globalization } \\
\text { National economic policies (e.g., market liberalization, } \\
\text { privatization, trade tariffs, subsidies) } \\
\text { Changing patterns of consumption } \\
\text { Changing livelihood opportunities and dependencies } \\
\text { Private sector investments and partnerships }\end{array}$ \\
\hline & & Costs and credit & $\begin{array}{l}\text { Increasing food costs } \\
\text { Rising livelihood costs (e.g., gear, fuel) } \\
\text { Access to credit }\end{array}$ \\
\hline & & Market demand and prices & $\begin{array}{l}\text { Changing demands for natural resource products } \\
\text { Changing market prices }\end{array}$ \\
\hline & $\begin{array}{l}\text { Infrastructure and } \\
\text { technology }\end{array}$ & $\begin{array}{l}\text { Increasing physical and } \\
\text { technological capacity } \\
\text { Coastal development }\end{array}$ & $\begin{array}{l}\text { Bigger boats, larger engines, improved gear } \\
\text { Navigation and fish-finding technology (e.g., sonar, GPS) } \\
\text { Urbanization and restructuring of coasts } \\
\text { Tourism infrastructure } \\
\text { Extractive industries (Sand, mining, gas projects) } \\
\text { Aquaculture and mariculture }\end{array}$ \\
\hline & & $\begin{array}{l}\text { Basic services and social } \\
\text { infrastructure }\end{array}$ & $\begin{array}{l}\text { Roads and public transportation } \\
\text { Schools, hospitals, electricity, water, waste treatment } \\
\text { Communication infrastructure and media }\end{array}$ \\
\hline & & $\begin{array}{l}\text { Engineered structures } \\
\text { Household }\end{array}$ & $\begin{array}{l}\text { Dams, levees } \\
\text { Household infrastructure } \\
\text { Household assets }\end{array}$ \\
\hline & $\begin{array}{l}\text { Governance and } \\
\text { policy }\end{array}$ & $\begin{array}{l}\text { Changing governance } \\
\text { institutions and } \\
\text { structures }\end{array}$ & $\begin{array}{l}\text { Organizational jurisdictions and mandates } \\
\text { Decision-making structures, processes (centralization, } \\
\text { inclusion, scale) and legitimacy } \\
\text { Societal norms and values } \\
\text { Networks of organizations and actors } \\
\text { Capacity and resourcing }\end{array}$ \\
\hline & & Changing regulations & $\begin{array}{l}\text { Changes in tenure and rights (property, harvest, access, } \\
\text { management) } \\
\text { Natural resource management, fisheries and conservation } \\
\text { policies } \\
\text { Market-driven changes in allocations and harvesting }\end{array}$ \\
\hline & & Conflict and security & $\begin{array}{l}\text { Conflicts between groups and resolution mechanisms } \\
\text { Politics and violence }\end{array}$ \\
\hline & Sociocultural & $\begin{array}{l}\text { Shifting traditions, } \\
\text { knowledge and } \\
\text { values }\end{array}$ & $\begin{array}{l}\text { Changing value systems } \\
\text { Loss or re-invigoration of traditional practices } \\
\text { Changing knowledge systems }\end{array}$ \\
\hline & & Networks and relationships & $\begin{array}{l}\text { Shifting family relationships and gender roles } \\
\text { Organizational networks and bridging social capital }\end{array}$ \\
\hline
\end{tabular}


may lead to local extinctions of fish populations, new species interactions and profound changes in marine food webs (Mueter and Litzow 2008). The southeastern Australian sea urchin, for example, has recently expanded its range into Tasmanian waters, where it has catalyzed a regime shift from macro-algal communities into urchin barrens (Ling 2008). In Norway, increases in ocean temperatures have driven collapses in the Barents Sea capelin stocks, with negative impacts on both Arcto-Norwegian cod stocks and the fishing communities in the region (Perry et al. 2011). Among the most significant influences of climate change on the world's oceans are its impacts on habitat-forming species such as corals. Mass coral bleaching and mortality, the result of increasing temperatures, is already reducing the richness and density of coral reef fishes with significant impact on reef fish and fisheries (Bellwood et al. 2006; Cinner et al. 2012b). Climate change is projected to change metabolic rates of marine species, reduce primary productivity and increase incidence of disease (O'Connor et al. 2009; McLeod et al. 2013). Climate change is also expected to challenge the ocean's capacity to meet the fish consumption demands of a growing human population (Merino et al. 2012).

\section{Other environmental}

Overfishing may outweigh all other pervasive human disturbances to coastal ecosystems, including anthropogenic climate change, pollution and degradation of water quality. Overfishing alters marine population demographics (removal of older individuals), spatial dynamics (changes in spawning grounds) and species abundance and thus reduces the ocean's ability to provide food, maintain water quality and recover from perturbations (Worm et al. 2006; Rockström et al. 2009a; Watson et al. 2014). Historic exploitation of sea otters in the Aleutian Islands removed the primary predator of sea urchins, resulting in massive deforestation of kelp forests via an unregulated sea urchin population (Steneck et al. 2002). The ability of Atlantic cod stocks to tolerate environmental variability has been eroded by fishing, which removes older fish and thus the buffering capacity provided by older individuals (Ottersen et al. 2006). Perhaps the most detrimental impact of overfishing on coastal systems is the negative effects on food and livelihood security for millions of smallscale fishers and their families particularly in the developing world. In Mozambique, for example, over $80 \%$ of smallscale fishers surveyed reported food insecurity, which they attributed to declining catch resulting from overfishing (Blythe et al. 2014). Within a few years, aquaculture's contribution to fish supply for human consumption will exceed that of wild capture fisheries and the industry stands to make important contributions to food security. However, the explosive development of coastal aquaculture has been criticized for the destruction of mangroves, saline intrusion, damaging runoff and collection of wild broodstock, as well as for forcing local stakeholders off their land and for converting multiple-use coastlines into single-use monocultures, and may pose a serious threat to the well-being of coastal communities (Duke et al. 2007; Paul and Vogl 2011; Zou et al. 2011). Many other forms of coastal development and land-use changes impact previous livelihoods.

Land-based activities produce profound impacts on coastal systems. Over the last five decades, conversion of forests and other ecosystems into agricultural land has occurred at an average global rate of $0.8 \%$ per year (Millenium Ecosystem Assessment 2005). The manufacture of fertilizer for food production and the cultivation of leguminous crops convert more nitrogen from the atmosphere into reactive forms than all of the Earth's terrestrial processes combined (Rockström et al. 2009b). Much of this new nitrogen ends up in the environment, polluting coastal zones and increasing incidence of hypoxia (Diaz and Rosenberg 2008). The extent and intensity of hypoxic zones in the Baltic Sea, for example, have increased dramatically during the last half-century with considerable impacts on biogeochemical processes, ecosystem services and coastal habitats (Conley et al. 2011). Annually over 8.5 million tonnes of phosphorous flow into the world's oceans, which is 8-9 times higher than the natural background rate (Rockström et al. 2009a). Phosphorus-induced anoxic events have been linked to mass extinctions of marine life (Handoh and Lenton 2003). Humans are currently the dominant driver of change in global river flow (Shiklomanov and Rodda 2004). An estimated $25 \%$ of the world's river basins run dry before reaching the oceans due to human use (Molden et al. 2007). Global manipulations of the freshwater cycle affect biodiversity, food and health security, and ecological functioning, such as provision of habitats for fish recruitment, carbon sequestration and climate regulation (Rockström et al. 2009b). In central Mozambique, poor dam management has contributed to severe flooding and villagers report saltwater spreading up the estuary when the dam is closed, which harms agricultural crops and contaminates drinking water (Bunce et al. 2010b). Furthermore, humans are increasing the river transport of sediment through soil erosion activities and decreasing transport to the coastal zone through sediment retention in reservoirs (Syvitski and Kettner 2011). Changes in sediment supply can create significant changes in the benthic environment of coastal estuaries, coral reefs, sea grass communities and coastal fisheries.

\section{Socioeconomic drivers, exposures and impacts}

\section{Demographic}

Earth's population is expected to grow by one billion between 2013 and 2025, reaching over 8 billion people 
(UNDP 2013). Rapid increase in population density has been prevalent in coastal zones, exposing coastal systems to new risks (Nelson et al. 2005; Mee 2012). For example, migration is one of the central drivers of increased exposure to flooding as low-lying coastal areas are becoming urbanized (Adelekan 2010; Hanson et al. 2011). In Kenya and Mozambique, increasing population along the coast, resulting from both local population growth and migration of people in search of economic opportunity, represents the main force exerting pressure on the coastal fishery (Mangi et al. 2007; Blythe et al. 2013). Brewer et al. (2012) demonstrate a negative relationship between coastal population density and the diversity and function of coral reef fishes.

Migration is another demographic change exerting pressures on coastal systems. For example, in Mozambique, fighting inland during the civil war drove millions of people to the coast, many of whom turned to fishing (Blythe et al. 2013). Migrant fishers can be marginalized in their new communities and exposed to poor living conditions, such as lack of safe drinking water or adequate living quarters (Njock and Westlund 2010). Gentrification in fishing communities in the USA, driven by increasing coastal populations, changing demographics, and a desire for access to natural amenities, is accelerating a move toward non-marine-based economies that displace local residents and their dependence on fishing (Colburn and Jepson 2012). Another dimension of coastal migration is the movement of young people out of fishing communities to larger urban centers, resulting in the aging of traditional fishing communities (Ommer and Team 2007).

\section{Economic}

The increasingly interconnected nature of our globalized economy can create opportunities and challenges for coastal communities. Increasing international trade has exposed local producers to boom and bust cycles associated with expanding luxury markets for marine products such as shrimp (Blythe et al. 2014), shark fins and sea cucumbers (Eriksson and Clarke 2015) and live reef fish (Fabinyi and Dalabajan 2011). In India, Chinese interest in a range of species that had previously been ignored by local fishers produced an export-induced economic surge in the coastal fishery in the late 1980s (Armitage and Johnson 2006). However, the boom proved unsustainable and collapsed following the Asian financial crisis in 1997. Trade-induced increases in demand for marine resources have also resulted in sequential depletions of internationally targeted species (Berkes et al. 2006). Unregulated harvest of green sea urchin, driven by demand from Japanese sushi markets, led to rapid stock depletion in Maine (Steneck et al. 2002). However, increasing international demand for sea cucumber has driven overexploitation of stocks in the Western Indian Ocean
(Eriksson et al. 2010). Changes in the compositions of people's diets, driven by rising per capita income and globalization of our food systems, have been characterized by less consumption of starchy staples (rice, wheat and potatoes) and more of fat, meat, fish, fruits and vegetables (Nelson et al. 2005). In some cases, this has led to better nutrition. However, in other cases, such as the Solomon Islands, traditional diets have been replaced by consumption of processed foods and associated with rising health concerns such as diabetes (Schwarz et al. 2011).

Coastal communities are vulnerable to drastic price changes driven by global market dynamics. In Mozambique, rising food prices have eroded traditional reciprocal sharing networks and worsened food insecurity (Bunce et al. 2010b; Blythe et al. 2014). Moreover, increasing prices for fuel have led to reduced fishing days (Tuler et al. 2008; Bunce et al. 2010b). These impacts are exacerbated for marginalized coastal people, including migrant and subsistence fishers, who typically do not have access to credit (Mills et al. 2011; Blythe et al. 2014). In some areas, declining prices for marine products are reducing fishers' income and driving increasing fishing pressure (Bennett et al. 2014b). Constantly shifting prices and seasonal demand for marine resources and tourism affect income and household stability (Tuler et al. 2008; Bennett et al. 2014b). In some cases, lower incomes have caused fishers to fish longer hours, in increasingly dangerous conditions (Tuler et al. 2013). Globalization has also driven a dramatic increase in international tourism, with varying results for coastal communities. On the Andaman coast of Thailand, for example, some people have profited from tourism through sales, restaurants and ocean tours, while others are experiencing loss of livelihood options due to exclusions from national marine parks (Bennett et al. 2014a). This example demonstrates how rapid and drastic changes in market characteristics and prices can benefit some and not others, which can reinforce inequities for vulnerable groups.

\section{Technology and infrastructure}

Coastal landscapes are being transformed as a consequence of new technology. Larger engines, more efficient gear and improved fish-finding capabilities have significantly changed our relationship with marine resources. In many countries, increasing fishing capacity has led to initial increases in marine landings, followed by a marked decline (Tuler et al. 2008; Perry et al. 2011; Blythe et al. 2013; Kittinger et al. 2013). In India, the rise of trawling combined with motorization of the small-scale fleet has led to conflicts between trawlers and small-scale fishers (Armitage and Johnson 2006). In Nunavut territory of Canada, new technologies, such as citizen band (CB) radios, global positioning systems (GPS), personal location beacons and 
consultation of satellite images of sea ice prior to travel, have both increased safety for Arctic hunters by allowing them to avoid dangerous areas and situations while increasing risks for less experienced hunters in the case of gear malfunction (Ford et al. 2006).

Rapid coastal development has many consequences. Close to one quarter of the world's population lives within $100 \mathrm{~km}$ of the coast, meaning that coastal systems have experienced disproportionately rapid expansion of economic activity and infrastructure development (Small and Nicholls 2003). Coastal dredging for land reclamation and port construction increases sedimentation and turbidity and has been linked with significantly higher incidence of coral disease in Western Australia (Pollock et al. 2014). Extractive industries, including mining and fossil fuel exploitation, can create exposure to new stressors in coastal communities. During the development of a gas project in Tanzania, promises of equipment that would allow fishers to fish offshore went unmet, villagers were forced to relocate, and protests escalated into violent conflicts (Bunce et al. 2010b).

In many areas, improvements in basic services have led to better access to markets, schools, hospitals and communication technologies, such as cell phones, with primarily positive impacts on coastal communities. Within weeks of installation of a cell tower in south India, the local price of fish converged where previously it varied highly from market to market (Jensen 2007). By calling ahead from sea, fishermen travelled to markets where fish were in low supply leading to an average $5 \%$ reduction in the price of fish for consumers and a $9 \%$ gain in income for fishers. Infrastructure developments such as increasing road access can reduce vulnerability in remote rural areas, which have been geographically isolated and characterized by high transaction costs, limited access to markets and low provision of government services or infrastructure (Béné 2009).

\section{Governance and policy}

Governance refers to the prevailing set of processes, institutions and policies through which the rules shaping the use of coastal resources are set and revised (Bennett 2015). Governance systems produce profound consequences for coastal communities and linked ecosystems. Organizational mandates, agency jurisdictions, formal decision-making structures and processes are often realigned by governments or through the interactions of influential stakeholders with the governance system (Ommer and Team 2007; Chuenpagdee 2011). Changing societal norms and values can also manifest in governance systems by stimulating new policy directions (e.g., in fisheries or conservation) and determining what constitutes appropriate governance processes (e.g., levels of participation, transparency, accountability). In general, institutions can serve as enablers or inhibitors of adaptive capacity and corrective adaptations (Tyler and Moench 2012) - for example, in the adoption of an ecosystem-based approach to climate change (Elrick-Barr et al. 2014; Lukasiewicz et al. 2015). Levels of resourcing and organizational capacity determine whether agencies are able to learn through research, engage with the knowledge produced and implement management actions (Jantarasami et al. 2010; Cvitanovic et al. 2014). Shifting relationships and levels of collaboration between networks of organizations and individuals involved in governance can also determine the level of participation of local communities and the effectiveness of coastal management initiatives (Bodin and Crona 2009; Alexander and Armitage 2015).

Governance structures and decision-making processes strongly affect whose voices are heard in decision-making and how local knowledge and needs are incorporated. This means that in order to engage local knowledge in evidencebased decision-making, governance processes themselves may need to be revised. There is a growing literature on the potential for combining local knowledge systems with scientific knowledge to cope with change in resource and ecosystem management (Haggan et al. 2007; Armitage et al. 2007). For example, in the Solomon Islands, indigenous knowledge and sea tenure systems were used in combination with scientific knowledge to establish marine protected areas for bumphead parrotfish conservation (Aswani and Hamilton 2004). Community-based and collaborative (e.g., co-management) initiatives have reduced exposure to threats such a stock declines (Pinto da Silva and Kitts 2006) and have created a greater degree of democracy in regard to resource governance (Cinner et al. 2012a) in many coastal communities, although the impacts of collaborative initiatives vary widely within the social-ecological complexity of coastal systems (Cohen and Alexander 2013).

In other cases, regulatory changes can create negative consequences for coastal communities when marine resources or spaces are reallocated or when "ocean grabbing" occurs (Bennett et al. 2015). The establishment of marine protected areas (MPAs) alters resource-use rights and has been associated with increasing incidence of elite control of resources, the exclusion of resource users and the criminalization of local people (West et al. 2006; Bennett and Dearden 2014). In Tanzania, conflict over resource access in a MPA escalated to the use of tear gas by police on local fishers (Bunce et al. 2010b). Even when reserves are specifically designated for the benefit of local users, such as the 3000-m limit in Thailand, conflict can arise between illegally fishing commercial vessels and small-scale fishers (Bennett et al. 2014b). Quota systems in the USA can increase unsafe decision-making and risk-taking by fishers (Tuler et al. 2008). For example, when a fishery is approaching its quota, fishers may race to finish their fishing before the quota is reached, even if it means venturing out in bad weather. Furthermore, 
consequences of regulatory change extend beyond those directly involved in marine resource harvesting. Tuler et al. (2013) documented how a regulatory change, introduced by the New England fishery Management Council in 2010, led to fewer fishing trips meaning that onshore workers lost hours and that the availability of dockage shrunk, since more vessels remained in port longer.

\section{Sociocultural}

In many coastal communities, concern about shifting values and norms is rising. Along numerous coasts, the use of marine resources has been regulated through taboos and beliefs controlled by community elders. These informal restrictions on fishing practices acted to maintain social control and access to common pool resources (Foale et al. 2011). Recently, many of these traditions have been eroded due to changing religious and cultural norms and declining interest of younger generations (Mangi et al. 2007; Blythe et al. 2013). A second, quite different impact of shifting values and norms can be seen in the Canadian Arctic. As Inuit hunters become more integrated into a "Western culture," traditional knowledge is being lost and risk-taking behavior has risen. Time off from formal employment must be booked months in advance, so hunters feel committed to a particular time regardless of weather or safety concerns (Aporta 2004). Younger hunters rely less on traditional knowledge and practice less caution due to perceived safety nets provided by technological developments (Ford et al. 2006). Changing family dynamics are creating exposure to new stressors. Following the cod moratorium in Newfoundland, Canada, some families replaced male fishing crew with wives in order to concentrate diminished earnings within the household (Grzetic 2004). In Kenya, the capacity to participate in traditional family reciprocity is being challenged by growing food insecurity (Casale et al. 2010). These examples reflect how shifting values and norms can create exposure to new stressors in coastal systems.

\section{Interactions between exposures and adaptations}

A key challenge for those living and working in coastal social-ecological systems is that multiple exposures do not simply converge-they interact. Moreover, most coastal systems are characterized not by single interactions between exposures but by multiple overlapping interactions. Furthermore, multiple exposures interact through autonomous, cascading, cross-scale and adaptive feedbacks leading to differential impacts and community social and ecological vulnerability outcomes depending on the context. Interactions and feedbacks can amplify, dampen or mitigate the impact of individual exposures. Due to the unlimited number of different contexts and factors involved, it is neither possible nor desirable to attempt to describe the multitude of expected and unexpected interactions between different exposures. Additionally, many impacts and interactions are unanticipated or novel, making vulnerability outcomes unpredictable. Below we provide two illustrative examples of interactions among exposures and adaptations.

In the coastal city of Quy Nhon, Vietnam, an analysis of sources of flood risk in peri-urban areas found that existing residents were placed at increased risk of catastrophic flooding due primarily to urban development patterns and livelihood threats, rather than climate and hydrological changes per se (DiGregorio and Huynh 2012). The lack of integration between construction of new transportation infrastructure, dikes, urban development zones with land fill to raise surface elevation and drainage in low-lying coastal floodplains combined with displacement due to urban land acquisition created a flood risk profile for community members that had increased in unexpected ways. While climate change was not yet a central factor in this case, increased likelihood of extreme climate events will contribute both to uncertainty and magnitude of adverse outcomes. This pattern of multiple exposure and unintended consequences creates dynamic and unanticipated risks for those community members who have limited choices.

The vast majority of the literature on interactions focuses only on the negative impacts of interacting stressors, neglecting to take into account the opportunities that can arise from macro- and mesoscale changes or the ways that responses (or adaptations) can amplify, dampen or mitigate single or multiple exposures. Our second example illustrates how drivers of change at various scales can interact to create both opportunities and constraints at the community scale. In the early 1990s in Mozambique, macroeconomic policy shifts (market liberalization) opened the economy to foreign investment for the first time, which led to the establishment of a French-owned, export-oriented shrimp farm on the central coast. The shrimp farm created local employment opportunities, benefitting several hundred people in a context where wage work is extremely limited. Yet, it also exposed shrimp farm employees to a new stressor (termination of their jobs due to shrimp disease outbreak) and it blocked access to previously communal land used by the greater community for making salt. As a result, people are moving into coastal fisheries, where climate changes are causing more frequent and severe storm events and increasing the risks fishers face at sea. Thus, macroscale drivers of changes created exposure to new stressors that created positive and negative impacts on community vulnerability (Blythe et al. 2015). 


\section{Assessing vulnerability and identifying adaptations: a pragmatic approach}

In this section, we propose a pragmatic yet comprehensive approach for assessing coastal community vulnerability based on the framework and typology introduced in the previous sections. The intent of this approach is to shift the analytical focus from a particular hazard or exposure to the community itself, which will inevitably be dealing with multiple exposures. The aim is to provide practical guidance to researchers, practitioners, managers and policy makers for identifying key drivers of change, exposures and impacts and for developing contextually appropriate response strategies without being overly prescriptive. In brief, the following elements are essential for analyzing social-ecological vulnerability and identifying adaptive responses.

1. Identify important social and ecological components of the system of interest and establish criteria for evaluating each component;

2. Characterize the nature and severity of socioeconomic and biophysical drivers and resulting exposures and potential impacts;

3. Describe the autonomous interactions and feedbacks between drivers, exposures and impacts within and between social and ecological systems;

4. Analyze components of latent adaptive capacity and potential barriers to adaptation;

5. Identify potential adaptations that reduce sensitivity or exposure, improve adaptive capacity and enhance social-ecological outcomes to individual stressors;

6. Characterize interactions resulting from adaptations (i.e., amplifying, dampening, and mitigating) and analyze trade-offs among social and ecological outcomes of potential adaptations;

7. Identify adaptations that lead to win-win and mostbenefit social-ecological outcomes;

8. Prioritize actions to reduce sensitivity, improve adaptive capacity and enhance social-ecological outcomes based on feasibility (adaptive capacity) and desirability (values) of outcomes;

9. Identify who is responsible for implementation and what resources will be provided; and

10. Implement, monitor and adapt.

These elements build on and extend rich literature in various fields. For example, there is extensive literature exploring characterization of social-ecological systems (Folke et al. 2003; Turner et al. 2003; Walker et al. 2004) and analysis of adaptive capacity (Marshall et al. 2010; Engle 2011; Bennett et al. 2014a). Climate change vulnerability and adaptation planning literature have emphasized important best practices-e.g., facilitating inclusive and place-based analyses, focusing on building adaptive capacity, strengthening institutions, integrating diverse knowledges, identifying no-regrets adaptations, prioritizing actions, clarifying resourcing and responsibility, understanding differential impacts, implementing cooperative and adaptive management (Smith et al. 2003; Leary et al. 2008; Burton 2009; Leary et al. 2009; Ensor and Berger 2009; Hall 2011; Bundy et al. 2015; Nalau et al. 2015). Yet, the majority of the previous literature has focused on single stressors and, in particular, climate change.

Lacking are simple methods for understanding vulnerability to multiple interacting exposures and clear and effective processes for identifying adaptations that take into account multiple exposures. Below we discuss methods for: (a) characterizing exposures and impacts, (b) interrogating the interactions between exposures and (c) identifying effective adaptations to multiple exposures that reduce sensitivity, increase adaptive capacity and enhance outcomes. Descriptions, uses and examples of applications of these methods are provided in Table 2.

\section{Characterizing exposures and impacts}

The majority of studies that have sought to characterize the nature and severity of exposures in a given locale have been externally driven efforts that focus on single hazards. We suggest that the typology presented here could provide a comprehensive frame of reference for future communitycentered vulnerability assessments using qualitative, quantitative or mixed methods with a focus on local perspectives and experiences. For example, each category of driver or type of exposure in the framework could be explored through qualitative interviews, or results emerging from interviews could be compared with or coded against the framework. Interviewing could be used to examine local perceptions of the presence or absence of specific exposures that are occurring in each locale, the severity of exposures and the drivers of local exposures (Blythe et al. 2015). Different exposures could be ranked by importance or rated (e.g., on a Likert scale of 1-5) to determine the relative severity of the exposure or the sensitivity of communities, households or groups (Tschakert 2007; Bennett et al. 2014b). As Eakin and Leurs (2006) argue, it is essential to distinguish the most relevant and impactful drivers. In particular, it is crucial to identify extreme events-e.g., irregular or unpredictable exposures to which communities are highly sensitive-and "Achilles heel" vulnerabilities-i.e., those slow variables that significantly outweigh other stressors and that might undermine adaptations if sensitivity is not reduced through 
mitigative actions. Two examples of acute exposures are the 2004 tsunami in Southeast Asia or rapid hypoxic events that undermine localized conservation measures. Examples of chronic stressors include the steadily increasing impacts of ocean acidification for the shellfish industry or of sea level rise for communities that are situated in low-lying coastal areas. Quantitative analysis of exposures would also allow for scaling up research for broader-scale comparisons of exposures, sensitivities and differential impacts-for example, among communities and across regions or countries (e.g., Cinner et al. 2011). Our typology could be used as the basis of participatory focus groups or discussions on historical, present or future changes (e.g., Bennett et al. 2014c). Yet, future work in this area needs to move beyond just describing the drivers and exposures to understanding their impact, importance, causal mechanisms and interactions between exposures (Bunce et al. 2010b).

\section{Exploring interactions}

The dynamic interactions between multiple exposures have been examined using numerous participatory, qualitative and/or quantitative methods. Qualitative, ethnographic and visual methods will lead to rich narratives and historical accounts of local experiences of the interactions between stressors (Moerlein and Carothers 2012; Bennett and Dearden 2013). For participatory methods, previous studies have used mental models (Bunce et al. 2010a, b), the Driver-Pressure-State-Impact-Response (DPSIR) framework (Mangi et al. 2007; Suckall et al. 2014) and community-based scenario planning processes (Bennett et al. 2014c) to explore interactions between stressors. The following qualitative or semiquantitative methods also show some promise for exploring interactions-Bayesian networks, inference trees, expert judgments, influence diagrams, participatory mapping, historical timelines, trend lines, importance-incidence charts and causal dynamics (Bunce et al. 2000; Tomei et al. 2006; Chevalier and Buckles 2008; Gregory et al. 2012; Chevalier and Buckles 2013; Ban et al. 2014). Quantitative methods and multivariate statistical approaches-including factorial multiple ANOVA, ANCOVA, regression, canonical correlation, multi-way frequency, logistic regression, discriminate function, non-metric, cluster and principle component analyses - can also be useful for exploring the relationships between interacting exposures (see Menzie et al. 2007). Spatial approaches (O'Brien et al. 2004) are also useful but may be more applicable at broader scales.

Researchers are applying a miscellany of methods in diverse contexts to understand the interactions between multiple exposures - usually with a greater focus on either the social or the ecological components of the system. We suggest that a more systematic approach is required. Mixed methods approaches and triangulation of data from perceptual studies, biophysical studies, historical methods and policy studies will create a cohesive picture of how different trends, shocks and adaptations are interacting. Multisited, spatial and historical accounts should be incorporated to help to reconcile different scales and speeds of change and to tease out the impact of contextual factors (e.g., geography, ecology, demographics, economics) and specific events. Whichever methods are employed, there is a need to better understand and typify whether the interactions are mitigative (o), amplifying (+) or dampening $(-)$ across different categories and indicators of social and ecological change and to demonstrate effect size-which will require meta-analyses drawing on the results of multiple local studies.

\section{Identifying and prioritizing adaptations}

The cataloging and ranking of exposures and their interactions may seem like an academic exercise. However, as Hall (2011) argues "...the relative importance of the various drivers and the pathways through which they might act must be weighed to help prioritize actions." This signals an important shift from research about change to research for change (Fazey et al. 2015). The identification and prioritization of effective adaptations, in the context of multiple interacting exposures, is a significant challenge requiring foresight and long-term thinking to avoid coping strategies or "manipulations" (Thomsen et al. 2012) that lead to maladaptations and increased sensitivity. Whenever possible, it behooves decision makers to identify first "noregrets" adaptations that reduce sensitivity and lead to win-win outcomes. Addressing shortcomings in some facets of adaptive capacity may always be a "no-regrets" solution (Adger et al. 2003). Resilience scholars suggest that organizational and institutional learning, diversity of livelihoods and knowledge, access to assets and adaptive co-management processes decrease vulnerability (Folke et al. 2003; Cinner et al. 2009; Bennett et al. 2014a). Mills et al. (2011) propose that non-sectoral interventions, such as improved community sanitation, might have the greatest effect on reducing vulnerability for the most people. However, it will often be necessary to recognize and make trade-offs in order to identify "least-harm" adaptations that will lead to the most beneficial outcomes.

In a similar manner to how interactions are classified, the mitigative (o), amplifying $(+)$ or dampening $(-)$ effects of potential adaptations on social and ecological outcome criteria might be explored. There are numerous trade-off approaches, deliberative decision-making methods and participatory research methods that can facilitate choice of adaptation in the face of multiple exposures such 
Table 2 Examples of methods for characterizing exposures and impacts, exploring interactions and identifying adaptations

\begin{tabular}{|c|c|c|c|}
\hline Topic & Methods & Description & Examples and references \\
\hline \multirow[t]{6}{*}{$\begin{array}{l}\text { Characterizing } \\
\text { Exposures } \\
\text { and Impacts } \\
\text { (Nature and } \\
\text { Severity) }\end{array}$} & $\begin{array}{l}\text { Qualitative } \\
\text { interviews }\end{array}$ & $\begin{array}{l}\text { Open-ended interviews with community members, knowledge holders } \\
\text { or experts allows for rich and contextualized narratives and } \\
\text { historical descriptions of perceived exposures, potential drivers and } \\
\text { associated risks or impacts. Perceptions are understood as relational } \\
\text { and subject to multiple meanings based on interpretations }\end{array}$ & $\begin{array}{l}\text { Bunce et al. (2010b), Fabinyi } \\
\text { (2010), Moerlein and Carothers } \\
\text { (2012), MacDonald et al. (2013), } \\
\text { Bennett et al. (2014b), McCubbin } \\
\text { et al. (2015) }\end{array}$ \\
\hline & $\begin{array}{l}\text { Participatory } \\
\text { methods }\end{array}$ & $\begin{array}{l}\text { Workshops or focus groups with stakeholders, decision makers and/or } \\
\text { experts can employ a variety of participatory methods to elicit lists, } \\
\text { narratives, matrices, historical timelines or artistic expressions of the } \\
\text { changes that are occurring and how these are impacting } \\
\text { communities. Severity can be documented numerically, through } \\
\text { participatory ranking or rating exercises, or qualitatively. Skilled } \\
\text { facilitation is required to ensure all voices are heard }\end{array}$ & $\begin{array}{l}\text { Kindon et al. (2007), Tschakert } \\
\text { (2007), CARE 2009, Mills et al. } \\
\text { (2011a), Chevalier and Buckles } \\
\text { (2013) }\end{array}$ \\
\hline & $\begin{array}{l}\text { Quantitative } \\
\text { rating or } \\
\text { ranking }\end{array}$ & $\begin{array}{l}\text { Household surveys in single or multiple sites can be used to } \\
\text { quantitatively rate or rank the impact of stressors or exposures on } \\
\text { different social, economic and ecological outcomes. Surveys allow } \\
\text { for incorporation of larger samples and comparison among groups } \\
\text { (livelihoods, genders, socioeconomic status, ethnicity), } \\
\text { communities, regions or countries. All exposures need to be } \\
\text { included }\end{array}$ & $\begin{array}{l}\text { Bunce et al. (2010b), Mills et al. } \\
\text { (2011a), Cinner et al. (2012b); } \\
\text { Bennett et al. (2014b), Blythe et al. } \\
\text { (2015) }\end{array}$ \\
\hline & $\begin{array}{l}\text { Spatial } \\
\text { approaches }\end{array}$ & $\begin{array}{l}\text { People's spatial knowledge of exposures and their impacts can be } \\
\text { elicited using participatory methods-e.g., collaborative mapping, } \\
\text { transect walks, hazard mapping, participatory geographic } \\
\text { information systems-and spatial information management tools. } \\
\text { Maps can also be useful tools for sharing and discussing interactions } \\
\text { and potential adaptations }\end{array}$ & $\begin{array}{l}\text { Ban et al. (2009), Raymond et al. } \\
\text { (2009) }\end{array}$ \\
\hline & $\begin{array}{l}\text { Expert } \\
\text { elicitation } \\
\text { techniques }\end{array}$ & $\begin{array}{l}\text { Opinions regarding exposures and their relative impacts can be } \\
\text { elicited from experts, who are knowledgeable about social or } \\
\text { ecological aspects of the system, through such methods as Bayesian } \\
\text { methods, Delphi processes or nominal groups. This can be done } \\
\text { individually or in a focus group setting }\end{array}$ & $\begin{array}{l}\text { Richards et al. (2013), Ban et al. } \\
\text { (2014) }\end{array}$ \\
\hline & $\begin{array}{l}\text { Arts-based } \\
\text { methods }\end{array}$ & $\begin{array}{l}\text { Various arts-based methods (e.g., participatory drawing, photovoice, } \\
\text { participatory video, photohistory, documentary film making, digital } \\
\text { storytelling) can provide in-depth empirical insights into exposures } \\
\text { and impacts to community well-being and environmental health. } \\
\text { These can serve as basis for conversations and deliberations around } \\
\text { adaptations }\end{array}$ & $\begin{array}{l}\text { Kunuk and Mauro (2010), Walker } \\
\text { (2012), Bennett and Dearden } \\
\text { (2013), Lemelin et al. (2013), } \\
\text { Willox et al. (2013) }\end{array}$ \\
\hline \multirow[t]{4}{*}{$\begin{array}{l}\text { Exploring } \\
\text { Interactions } \\
\text { (Additive or } \\
\text { Dampening) }\end{array}$} & $\begin{array}{l}\text { Mental } \\
\text { models }\end{array}$ & $\begin{array}{l}\text { Mental models are people's cognitive frameworks of the world. They } \\
\text { can provide insights into perceived relationships and feedbacks } \\
\text { between different exposures. Data are collected through individual } \\
\text { or group interviews and analyzed using content analysis, procedural } \\
\text { mapping, task analysis, cognitive mapping and consensus analysis }\end{array}$ & $\begin{array}{l}\text { Bunce et al. (2010b), Jones et al. } \\
\text { (2011), Lynam et al. (2012) }\end{array}$ \\
\hline & $\begin{array}{l}\text { Drivers- } \\
\text { Pressures- } \\
\text { States- } \\
\text { Impacts- } \\
\text { Responses }\end{array}$ & $\begin{array}{l}\text { The DPSIR framework provides a tool to organize information on } \\
\text { drivers, exposures (pressures) and impacts (states and impacts) on } \\
\text { social and ecological outcomes (states). The DPSIR framework can } \\
\text { help to identify trade-offs between adaptation, mitigation and } \\
\text { development response options and to avoid maladaptations. Does } \\
\text { not help to understand bridges, barriers or steps to achieve actions }\end{array}$ & $\begin{array}{l}\text { Tscherning et al. (2012); Suckall } \\
\text { et al. (2014), Maccarrone et al. } \\
\text { (2014), Breslow (2015) }\end{array}$ \\
\hline & $\begin{array}{l}\text { Participatory } \\
\text { methods }\end{array}$ & $\begin{array}{l}\text { Participatory methods, such as force field, causal dynamics, } \\
\text { vulnerability matrix, influence diagrams, can be used to assess the } \\
\text { perceived level of positive or negative impact of key factors (drivers } \\
\text { and exposures) on social and/or ecological problems and to identify } \\
\text { how these factors interact to produce net positive, negative or } \\
\text { neutral outcomes }\end{array}$ & $\begin{array}{l}\text { Chevalier and Buckles (2008), } \\
\text { CARE (2009), Mills et al. (2011b), } \\
\text { Gregory et al. (2012), Chevalier } \\
\text { and Buckles (2013) }\end{array}$ \\
\hline & $\begin{array}{l}\text { Quantitative } \\
\text { and } \\
\text { multivariate } \\
\text { analyses }\end{array}$ & $\begin{array}{l}\text { Multiple case studies, meta-analyses or a systematic reviews would } \\
\text { allow for quantitative comparisons and multivariate analyses (e.g., } \\
\text { factorial multiple ANOVA, ANCOVA, regression, canonical } \\
\text { correlation, multi-way frequency, logistic regression, discriminate } \\
\text { function, non-metric, cluster and principle component analyses) to } \\
\text { explore relationships between interacting exposures }\end{array}$ & Menzie et al. (2007) \\
\hline
\end{tabular}


Table 2 continued

\begin{tabular}{|c|c|c|c|}
\hline Topic & Methods & Description & Examples and references \\
\hline & $\begin{array}{l}\text { Spatial } \\
\text { approaches }\end{array}$ & $\begin{array}{l}\text { See above description. Interactions between the different exposures } \\
\text { might also be explored using spatial overlays and qualitative } \\
\text { discussions of maps }\end{array}$ & (O’Brien et al. 2004) \\
\hline \multirow[t]{5}{*}{$\begin{array}{l}\text { Identifying and } \\
\text { Prioritizing } \\
\text { Responses } \\
\text { (Amplifying, } \\
\text { Mitigative and } \\
\text { Adaptive) }\end{array}$} & $\begin{array}{l}\text { Structured } \\
\text { decision- } \\
\text { making }\end{array}$ & $\begin{array}{l}\text { Structured decision-making (SDM) is an approach that seeks to } \\
\text { identify options, evaluate the outcomes of alternate courses of } \\
\text { action, find "win-win" solutions, clarify trade-offs and provide a } \\
\text { space for communicating views regarding options and trade-offs. It } \\
\text { does not provide solutions but can inform deliberations on difficult } \\
\text { decisions while making processes transparent and efficient. SDM } \\
\text { employs rigorous decision-making methods, such as strategy tables, } \\
\text { consequence tables, participatory cost-benefit analysis, to identify } \\
\text { trade-offs and prioritize responses }\end{array}$ & $\begin{array}{l}\text { (Espinosa-Romero et al. 2011; } \\
\text { Gregory et al. 2012) }\end{array}$ \\
\hline & $\begin{array}{l}\text { Multi-criteria } \\
\text { decision } \\
\text { analysis }\end{array}$ & $\begin{array}{l}\text { Stakeholder judgments are used to evaluate different alternatives or } \\
\text { options using ranking or weighting algorithms. The results can be } \\
\text { communicated to facilitate decision-making. Primary data (from } \\
\text { document reviews, interviews or focus groups) are required to } \\
\text { identify the range of options. MCDA is useful when decisions } \\
\text { involve uncertainty but need to be made quickly }\end{array}$ & $\begin{array}{l}\text { (Kiker et al. 2005; Scheuer et al } \\
\text { 2011; Porthin et al. 2013; } \\
\text { Sahin et al. 2013; Munaretto } \\
\text { et al. 2014) }\end{array}$ \\
\hline & $\begin{array}{l}\text { Cost-benefit } \\
\text { and cost- } \\
\text { effectiveness } \\
\text { analysis }\end{array}$ & $\begin{array}{l}\text { Cost-benefit and cost-effectiveness analysis provides tools for } \\
\text { comparing net economic efficiencies of adaptation options across } \\
\text { multiple climatic and other exposures. It is useful for examining } \\
\text { public policies or actions when key effects can be easily monetized }\end{array}$ & $\begin{array}{l}\text { (Leary 1999; Wegner and } \\
\text { Pascual 2011; Kull et al. } 2013 \\
\text { Mechler and Nabiul Islam } \\
\text { 2013; Watkiss et al. 2014; Nay } \\
\text { et al. 2014) }\end{array}$ \\
\hline & $\begin{array}{l}\text { Futures, } \\
\text { planning and } \\
\text { deliberation } \\
\text { methods }\end{array}$ & $\begin{array}{l}\text { Futures planning methods-e.g., scenario planning, visioning, } \\
\text { backcasting, participatory integrated assessments, adaptation } \\
\text { pathways approaches, transformation planning-can provide a } \\
\text { forum for exploring possible and/or desirable futures given current } \\
\text { and unknown trends or shocks and deliberating on response } \\
\text { strategies. Analysis of drivers, exposures, impacts, responses and } \\
\text { outcomes can be done using participatory, technological or } \\
\text { combined approaches }\end{array}$ & $\begin{array}{l}\text { (Swart et al. 2004; Evans et al. } \\
\text { 2006; Salter et al. 2010; } \\
\text { Sheppard et al. 2011; Cinner } \\
\text { et al. 2011; Smith et al. 2013; } \\
\text { Hamilton et al. 2013; Moore } \\
\text { et al. 2014; Butler et al. 2014; } \\
\text { Wise et al. 2014; Reid et al. } \\
\text { 2014) }\end{array}$ \\
\hline & $\begin{array}{l}\text { Multiple case } \\
\text { study } \\
\text { comparisons, } \\
\text { synthesis and } \\
\text { historical } \\
\text { methods }\end{array}$ & $\begin{array}{l}\text { Methods that draw on multiple case studies and historical cases for } \\
\text { syntheses or comparisons provide a tool for identifying similar cases } \\
\text { and insights into past adaptations that have worked. These } \\
\text { understandings can provide general lessons that can be applied to } \\
\text { current contexts }\end{array}$ & $\begin{array}{l}\text { (Bussey et al. 2012; Bundy et al } \\
\text { 2015; Fazey et al. 2015) }\end{array}$ \\
\hline
\end{tabular}

as: structured decision-making processes (EspinosaRomero et al. 2011; Gregory et al. 2012), participatory and weighted multi-criteria analysis (Scheuer et al. 2011; Heck et al. 2011; Bhave et al. 2014), quantitative or qualitative cost-benefit analysis (van den Bergh 2004) or the (DPSIR) framework (Mangi et al. 2007; Suckall et al. 2014). Efforts to identify adaptations could also draw on future methodologies such as scenario planning, visioning or backcasting (Berkhout et al. 2002; Kloprogge and Sluijs 2006; Sheppard et al. 2011; Hamilton et al. 2013; Evans et al. 2013).

Whichever approach is used to select adaptation actions, a number of important decision criteria should be incorporated from earlier steps in the analysis including: key social and ecological system components to maintain system stability; normative criteria and values for social and ecological outcomes; nature and severity of drivers and exposures; contextual factors that influence sensitivity; potential impacts on social-ecological systems; interactions among stressors and resulting from adaptations; and the feasibility of and barriers to adaptations based on adaptive capacity and institutional context. Exploring these criteria may require using several different decision-making approaches in combination. Qualitative or quantitative analysis of trade-offs will not lead to decisions but can contribute to evidence-based deliberative decision-making processes that incorporate various perspectives and values. Further work is needed that compares the processes, outputs and outcomes of the different decision-making tools and trade-off approaches, particularly in the context of adaptation planning. A review and comparison of the strengths, weaknesses, insights and implications of different approaches for assessing adaptive capacity is also warranted. 


\section{Concluding thoughts}

In this paper, we provided a framework and typology of drivers and exposures to analyze community social-ecological vulnerability and suggested processes and methods for better understanding how multiple interacting exposures act on coastal communities. We hope that this article will provide stimulus for future empirical work on vulnerability and adaptation to multiple interacting exposures, including facilitating further exploration of interactions, broader-scale analyses and comparisons between sites. However, we want to emphasize that this is not just an academic exercise. Change is a ubiquitous force that has very real impacts for communities and the ecosystems on which they rely. Management interventions tend to be driven by the policy $\mathrm{du}$ jour-whether it is biodiversity conservation, marine protected areas, climate change adaptation or disaster management-resulting in a narrow analytical focus that ignores or downplays the complications of multiple interacting exposures. This can result in the identification and implementation of well-intended policy and expensive programmatic responses that do not adequately address the issues or, worse yet, that further exacerbate sustainability challenges for local communities. We contend that our framework, typology and pragmatic approach will improve understanding of the types of socioeconomic and biophysical changes occurring and how these are interacting and impacting communities in order to identify more effective leverage points (whether via local actions or broader policies and programs) within the system for decreasing the vulnerability of communities to change.

Acknowledgments The initial meeting that led to this paper was hosted by the Centre for Global Studies at the University of Victoria. The lead author (NJB) was supported by a SSHRC Postdoctoral Fellowship and a Liber Ero Fellowship during the writing of this manuscript. All authors would like to acknowledge the support of their respective institutions.

Open Access This article is distributed under the terms of the Creative Commons Attribution 4.0 International License (http://creative commons.org/licenses/by/4.0/), which permits unrestricted use, distribution, and reproduction in any medium, provided you give appropriate credit to the original author(s) and the source, provide a link to the Creative Commons license, and indicate if changes were made.

\section{References}

Adelekan IO (2010) Vulnerability of poor urban coastal communities to flooding in Lagos, Nigeria. Environ Urban 22:433-450. doi:10.1177/0956247810380141

Adger WN (2006) Vulnerability. Glob Environ Change 16:268-281. doi:10.1016/j.gloenvcha.2006.02.006

Adger WN, Huq S, Brown K et al (2003) Adaptation to climate change in the developing world. Progress Dev Stud 3:179-195. doi:10.1191/1464993403ps060oa
Adger WN, Dessai S, Goulden M et al (2009a) Are there social limits to adaptation to climate change? Clim Change 93:335-354. doi:10.1007/s10584-008-9520-z

Adger WN, Lorenzoni I, O’Brien KL (2009b) Adapting to Climate Change: Thresholds, Values, Governance. Cambridge University Press, Cambridge, UK

Adger WN, Barnett J, Brown K et al (2013) Cultural dimensions of climate change impacts and adaptation. Nat Clim Change 3:112-117. doi:10.1038/nclimate1666

Alexander SM, Armitage D (2015) A social relational network perspective for MPA science: social networks for MPA science. Conserv Lett 8:1-13. doi:10.1111/conl.12090

Aporta C (2004) Routes, trails and tracks: trail breaking among the Inuit of Igloolik. Études/Inuit/Studies 28:9. doi:10.7202/013194ar

Armitage D, Johnson D (2006) Can resilience be reconciled with globalization and the increasingly complex conditions of resource degradation in Asian coastal regions? Ecol Soc 11

Armitage DR, Berkes F, Doubleday N (2007) Adaptive co-management: collaboration, learning, and multi-level governance. UBC Press, Vancouver

Aswani S, Hamilton RJ (2004) Integrating indigenous ecological knowledge and customary sea tenure with marine and social science for conservation of bumphead parrotfish (Bolbometopon muricatum) in the Roviana Lagoon, Solomon Islands. Environ Conserv 31:69-83. doi:10.1017/S037689290400116X

Ban NC, Picard CR, Vincent ACJ (2009) Comparing and integrating community-based and science-based approaches to prioritizing marine areas for protection. Conserv Biol 23:899-910. doi:10. $1111 /$ j.1523-1739.2009.01185.x

Ban SS, Pressey RL, Graham NAJ (2014) Assessing interactions of multiple stressors when data are limited: a Bayesian belief network applied to coral reefs. Glob Environ Change 27:64-72. doi:10.1016/j.gloenvcha.2014.04.018

Bellwood DR, Hoey AS, Ackerman JL, Depczynski M (2006) Coral bleaching, reef fish community phase shifts and the resilience of coral reefs. Glob Change Biol 12:1587-1594. doi:10.1111/j. 1365-2486.2006.01204.x

Béné C (2009) Are fishers poor or vulnerable? Assessing economic vulnerability in small-scale fishing communities. J Dev Stud 45:911-933. doi:10.1080/00220380902807395

Bennett NJ (2015) Governing marine protected areas in an interconnected and changing world. Conserv Biol 29:303-306. doi:10. 1111/cobi. 12458

Bennett NJ, Dearden P (2013) A picture of change: using photovoice to explore social and environmental change in coastal communities on the Andaman Coast of Thailand. Local Environ Int J Justice Sustain 18:983-1001. doi:10.1080/13549839.2012. 748733

Bennett NJ, Dearden P (2014) Why local people do not support conservation: community perceptions of marine protected area livelihood impacts, governance and management in Thailand. Marine Policy 44:107-116. doi:10.1016/j.marpol. 2013.08.017

Bennett NJ, Dearden P, Murray G, Kadfak A (2014a) The capacity to adapt?: communities in a changing climate, environment, and economy on the northern Andaman coast of Thailand. Ecol Soc 19:5. doi:10.5751/ES-06315-190205

Bennett NJ, Dearden P, Peredo AM (2014b) Vulnerability to multiple stressors in coastal communities: a study of the Andaman Coast of Thailand. Clim Dev

Bennett NJ, Kadfak A, Dearden P (2014c) Drawing the Future Together: Adapting to Change and Creating the Community and Environment That We Envision. Marine Protected Areas Research Group. University of Victoria, Victoria

Bennett NJ, Govan H, Satterfield T (2015) Ocean grabbing. Marine Policy 57:61-68. doi:10.1016/j.marpol.2015.03.026 
Berkes F (2007) Understanding uncertainty and reducing vulnerability: lessons from resilience thinking. Nat Hazards 41:283-295. doi:10.1007/s11069-006-9036-7

Berkes F, Folke C (1998) Linking social and ecological systems: Management pratices and social mechanisms for building resilience. Cambridge University Press, Cambridge

Berkes F, Colding J, Folke C (2003) Navigating social-ecological systems: Building resilience for complexity and change. Cambridge University Press, London

Berkes F, Hughes TP, Steneck RS et al (2006) Globalization, roving bandits, and marine resources. Science 311:1557-1558. doi:10. 1126/science. 1122804

Berkhout F, Hertin J, Jordan A (2002) Socio-economic futures in climate change impact assessment: using scenarios as [']learning machines'. Glob Environ Change 12:83-95. doi:10.1016/S09593780(02)00006-7

Bhave AG, Mishra A, Raghuwanshi NS (2014) A combined bottomup and top-down approach for assessment of climate change adaptation options. J Hydrol 518:150-161. doi:10.1016/j.jhydrol. 2013.08.039

Blythe JL, Murray G, Flaherty MS (2013) Historical perspectives and recent trends in the coastal Mozambican fishery. Ecol Soc 18:65. doi:10.5751/ES-05759-180465

Blythe JL, Murray G, Flaherty M (2014) Strengthening threatened communities through adaptation: insights from coastal Mozambique. Ecol Soc 19:6. doi:10.5751/ES-06408-190206

Blythe J, Flaherty M, Murray G (2015) Vulnerability of coastal livelihoods to shrimp farming: insights from Mozambique. Ambio 44:275-284. doi:10.1007/s13280-014-0574-Z

Bodin Ö, Crona BI (2009) The role of social networks in natural resource governance: what relational patterns make a difference? Glob Environ Change 19:366-374. doi:10.1016/j.gloenvcha. 2009.05.002

Breslow SJ (2015) Accounting for neoliberalism: "Social drivers" in environmental management. Marine Policy. doi:10.1016/j.mar pol.2014.11.018

Brewer TD, Cinner JE, Fisher R et al (2012) Market access, population density, and socioeconomic development explain diversity and functional group biomass of coral reef fish assemblages. Glob Environ Change 22:399-406. doi:10.1016/j. gloenvcha.2012.01.006

Brklacich M, Chazan M, Bohle H-G (2009) Human Security, Vulnerability, and Global Environmental Change. In: Matthew RA, Barnett J, McDonald B, O'Brien KL (eds) Global Environmental Change and Human Security. MIT Press, Cambridge, pp 35-52

Bunce L, Townsley P, Pomeroy R, Pollnac R (2000) ) Socioeconomic manual for coral reef management. Global Coral Reef Monitoring Network. Australian Inst. Marine Science, Townsville

Bunce M, Brown K, Rosendo S (2010a) Policy misfits, climate change and cross-scale vulnerability in coastal Africa: how development projects undermine resilience. Environ Sci Policy 13:485-497. doi:10.1016/j.envsci.2010.06.003

Bunce M, Rosendo S, Brown K (2010b) Perceptions of climate change, multiple stressors and livelihoods on marginal African coasts. Environ Dev Sustain 12:407-440. doi:10.1007/s10668-009-9203-6

Bundy A, Chuenpagdee R, Cooley SR et al (2015) A decision support tool for response to global change in marine systems: the IMBERADApT framework. Fish Fish. online. doi:10.1111/faf.12110

Burton I (2009) The Earthscan reader on adaptation to climate change. Earthscan, London

Burton I, Kates RW, White GF (1993) The environment as hazard, Second. Guilford Press, New York

Busch DS, Harvey CJ, McElhany P (2013) Potential impacts of ocean acidification on the Puget Sound food web. ICES J Mar Sci 70:823-833. doi:10.1093/icesjms/fst061
Bussey M, Carter RW, Keys N et al (2012) Framing adaptive capacity through a history-futures lens: lessons from the South East Queensland climate adaptation research initiative. Futures 44:385-397. doi:10.1016/j.futures.2011.12.002

Butler JRA, Suadnya W, Puspadi K et al (2014) Framing the application of adaptation pathways for rural livelihoods and global change in eastern Indonesian islands. Glob Environ Change 28:368-382. doi:10.1016/j.gloenvcha.2013.12.004

CARE (2009) Climate Vulnerability and Capacity Analysis. CARE International, London

Casale M, Drimie S, Quinlan T, Ziervogel G (2010) Understanding vulnerability in southern Africa: comparative findings using a multiple-stressor approach in South Africa and Malawi. Reg Environ Change 10:157-168. doi:10.1007/s10113-009-0103-y

Chambers R, Conway G (1992) Sustainable rural livelihoods: Practical concepts for the 21st century. University of Sussex, Sussex, IDS

Chevalier JM, Buckles DJ (2008) SAS2 A Guide to Collaborative Inquiry and Social Engagement. Sage/IDRC, Thousand Oaks

Chevalier JM, Buckles DJ (2013) Participatory action research: Theory and methods for engaged inquiry. Routledge, New York

Chuenpagdee R (2011) InteractIve governance for marIne conservatIon: an IllustratIon. Bull Mar Sci 87:197-211. doi:10.5343/ bms.2010.1061

Church JA, White NJ (2011) Sea-level rise from the late 19th to the early 21st century. Surv Geophys 32:585-602. doi:10.1007/ s10712-011-9119-1

Cinner JE, Fuentes M, Randriamahazo H (2009) Exploring social resilience in Madagascar's marine protected areas. Ecol Soc 14:41

Cinner JE, Folke C, Daw T, Hicks CC (2011) Responding to change: using scenarios to understand how socioeconomic factors may influence amplifying or dampening exploitation feedbacks among Tanzanian fishers. Glob Environ Change 21:7-12. doi:10.1016/j.gloenvcha.2010.09.001

Cinner JE, Daw TM, McClanahan TR et al (2012a) Transitions toward co-management: the process of marine resource management devolution in three east African countries. Glob Environ Change 22:651-658. doi:10.1016/j.gloenvcha.2012.03.002

Cinner JE, McClanahan TR, Graham NAJ et al (2012b) Vulnerability of coastal communities to key impacts of climate change on coral reef fisheries. Glob Environ Change 22:12-20. doi:10. 1016/j.gloenvcha.2011.09.018

Cohen PJ, Alexander TJ (2013) Catch rates, composition and fish size from reefs managed with periodically-harvested closures. PLoS ONE 8:e73383. doi:10.1371/journal.pone.0073383

Colburn LL, Jepson M (2012) Social indicators of gentrification pressure in fishing communities: a context for social impact assessment. Coast Manag 40:289-300. doi:10.1080/08920753. 2012.677635

Conley DJ, Carstensen J, Aigars J et al (2011) Hypoxia is increasing in the coastal zone of the Baltic Sea. Environ Sci Technol 45:6777-6783. doi:10.1021/es201212r

Cvitanovic C, Marshall NA, Wilson SK et al (2014) Perceptions of Australian marine protected area managers regarding the role, importance, and achievability of adaptation for managing the risks of climate change. Ecol Soc. doi:10.5751/ES-07019-190433

Diaz RJ, Rosenberg R (2008) Spreading dead zones and consequences for marine ecosystems. Science 321:926-929. doi:10.1126/ science. 1156401

DiGregorio M, Huynh CV (2012) Living with Floods: A Grassroots Analysis of the Causes and Impacts of Typhoon Mirinae. ISETVietnam, Hanoi

Doney SC, Fabry VJ, Feely RA, Kleypas JA (2009) Ocean acidification: the other CO2 problem. Ann Rev Marine Sci 1:169-192. doi:10.1146/annurev.marine.010908.163834 
Duke NC, Meynecke J-O, Dittmann S et al (2007) A world without mangroves? Science 317:41-42

Eakin H (2005) Institutional change, climate risk, and rural vulnerability: cases from Central Mexico. World Dev 33:1923-1938. doi:10.1016/j.worlddev.2005.06.005

Eakin H, Luers AL (2006) Assessing the vulnerability of socialenvironmental systems. Annu Rev Environ Resour 31:365-394. doi:10.1146/annurev.energy.30.050504.144352

Ellis F (2000) Rural livelihoods and diversity in developing countries. Oxford Univ. Press, Oxford

Elrick-Barr CE, Preston BL, Thomsen DC, Smith TF (2014) Toward a new conceptualization of household adaptive capacity to climate change: applying a risk governance lens. Ecol Soc. doi:10.5751/ES-06745-190412

Engle NL (2011) Adaptive capacity and its assessment. Glob Environ Change 21:647-656. doi:10.1016/j.gloenvcha.2011.01.019

Ensor J, Berger R (2009) Understanding climate change adaptation: lessons from community-based approaches. Practical Action Publishing, Rugby

Eriksen S, Aldunce P, Bahinipati C et al (2011) When not every response to climate change is a good one: identifying principles for sustainable adaptation. Clim Dev 3:7-20. doi:10.3763/cdev. 2010.0060

Eriksson H, Clarke S (2015) Chinese market responses to overexploitation of sharks and sea cucumbers. Biol Conserv 184:163-173. doi:10.1016/j.biocon.2015.01.018

Eriksson BH, de la Torre-Castro M, Eklöf J, Jiddawi N (2010) Resource degradation of the sea cucumber fishery in Zanzibar, Tanzania: a need for management reform. Aquat Living Resour 23:387-398. doi:10.1051/alr/2011002

Espinosa-Romero MJ, Chan KMA, McDaniels T, Dalmer DM (2011) Structuring decision-making for ecosystem-based management. Marine Policy 35:575-583. doi:10.1016/j.marpol.2011.01.019

Evans K, Valarde SJ, Prieto RP et al (2006) Field guide to the future: Four ways for communities to think ahead. CIFOR, New Orleans

Evans LS, Hicks CC, Fidelman P et al (2013) Future scenarios as a research tool: investigating climate change impacts, adaptation options and outcomes for the great barrier reef, Australia. Hum Ecol 41:841-857. doi:10.1007/s10745-013-9601-0

Fabinyi M (2010) The intensification of fishing and the rise of tourism: competing coastal livelihoods in the Calamianes Islands, Philippines. Human Ecol 38:415-427. doi:10.1007/ s10745-010-9329-z

Fabinyi M, Dalabajan D (2011) Policy and practice in the live reef fish for food trade: a case study from Palawan, Philippines. Marine Policy 35:371-378. doi:10.1016/j.marpol.2010.11.001

Fabricius KE, Langdon C, Uthicke S et al (2011) Losers and winners in coral reefs acclimatized to elevated carbon dioxide concentrations. Nat Clim Change 1:165-169. doi:10.1038/ nclimate 1122

Fazey I, Wise RM, Lyon C et al (2015) Past and future adaptation pathways. Climate and Development. doi:10.1080/17565529. 2014.989192

Feely RA, Orr J, Fabry VJ, et al (2009) Present and future changes in seawater chemistry due to ocean acidification. In: Mcpherson BJ, Sundquist ET (eds) Carbon sequestration and its role in the global carbon cycle. American Geophysical Union, pp 175-188

Foale S, Cohen P, Januchowski-Hartley S et al (2011) Tenure and taboos: origins and implications for fisheries in the Pacific. Fish Fish 12:357-369. doi:10.1111/j.1467-2979.2010.00395.x

Folke C, Colding J, Berkes F (2003) Synthesis: Building resilience and adaptive capacity in social-ecological systems. In: Berkes F, Colding J, Folke C (eds) Navigating social-ecological systems: Building resilience for complexity and change. Cambridge University Press, Cambridge; New York, pp 352-387
Ford JD, Smit B, Wandel J, MacDonald J (2006) Vulnerability to climate change in Igloolik, Nunavut: what we can learn from the past and present. Polar Record 42:127-138. doi:10.1017/ S0032247406005122

Friedman TL (2013) The scary hidden stressor. The New York Times SR11

Gregory R, Failing L, Harstone M et al (2012) Structured Decision Making: A Practical Guide to Environmental Management Choices. John Wiley \& Sons, Chichester

Grzetic B (2004) Women Fishes These Days. Fernwood, Halifax

Gunderson L, Pritchard L (2002) Resilience and the behavior of large scale systems. Island Press, Washington

Haggan N, Neis B, Baird I (eds) (2007) Fishers' knowledge in fisheries science and management. UNESCO Pub, Paris

Hall SJ (2011) Climate Change and Other External Drivers in SmallScale Fisheries: Practical Steps for Responding. In: Pomeroy RS, Andrew N (eds) Small-scale Fisheries Management: Frameworks and Approaches for the Developing World. CABI, Cambridge, pp 132-159

Hamilton MC, Thekdi SA, Jenicek EM et al (2013) Case studies of scenario analysis for adaptive management of natural resource and infrastructure systems. Environ Syst Decis 33:89-103. doi:10.1007/s10669-012-9424-3

Handoh IC, Lenton TM (2003) Periodic mid-Cretaceous oceanic anoxic events linked by oscillations of the phosphorus and oxygen biogeochemical cycles. Global Biogeochem Cycles 17:1092. doi:10.1029/2003GB002039

Hanson S, Nicholls R, Ranger N et al (2011) A global ranking of port cities with high exposure to climate extremes. Clim Change 104:89-111. doi:10.1007/s10584-010-9977-4

Heck N, Dearden P, McDonald A (2011) Stakeholders' expectations towards a proposed marine protected area: a multi-criteria analysis of MPA performance criteria. Ocean Coast Manag 54:687-695. doi:10.1016/j.ocecoaman.2011.07.003

Hicks CC, Cinner JE (2014) Social, institutional, and knowledge mechanisms mediate diverse ecosystem service benefits from coral reefs. PNAS. doi:10.1073/pnas.1413473111

Holling CS (2001) Understanding the complexity of economic, ecological, and social systems. Ecosystems 4:390-405. doi:10. 1007/s10021-001-0101-5

IPCC (2014) Climate change 2014: impacts, adaptation and vulnerability. Cambridge University Press, Cambridge, New York

Jantarasami LC, Lawler JJ, Thomas CW (2010) Institutional barriers to climate change adaptation in US national parks and forests. Ecol Soc 15:33

Jensen R (2007) The digital provide: information (Technology), market performance, and welfare in the south Indian fisheries sector. Q J Econ 122:879-924. doi:10.1162/qjec.122.3.879

Jones N, Ross H, Lynam T, et al (2011) Mental models: an interdisciplinary synthesis of theory and methods. Ecol Soc 16(1):46

Keeling RF, Körtzinger A, Gruber N (2010) Ocean deoxygenation in a warming world. Ann Rev Marine Sci 2:199-229. doi:10.1146/ annurev.marine.010908.163855

Kiker GA, Bridges TS, Varghese A et al (2005) Application of multicriteria decision analysis in environmental decision making. Integr Environ Assess Manag 1:95-108. doi:10.1897/ IEAM_2004a-015.1

Kindon S, Pain R, Kesby M (2007) Participatory action research approaches and methods: connecting people, participation and place. Routledge, New York

Kittinger JN, Finkbeiner EM, Ban NC et al (2013) Emerging frontiers in social-ecological systems research for sustainability of smallscale fisheries. Current Opinion in Environmental Sustainability 5:352-357. doi:10.1016/j.cosust.2013.06.008 
Kloprogge P, Sluijs JPVD (2006) The inclusion of stakeholder knowledge and perspectives in integrated assessment of climate change. Clim Change 75:359-389. doi:10.1007/s10584-006-0362-2

Knutson TR, McBride JL, Chan J et al (2010) Tropical cyclones and climate change. Nature Geosci 3:157-163. doi:10.1038/ ngeo779

Kroeker KJ, Kordas RL, Crim RN, Singh GG (2010) Meta-analysis reveals negative yet variable effects of ocean acidification on marine organisms. Ecol Lett 13:1419-1434. doi:10.1111/j.14610248.2010.01518.x

Kull D, Mechler R, Hochrainer-Stigler S (2013) Probabilistic costbenefit analysis of disaster risk management in a development context - kull - 2013 - disasters - wiley online library. Disasters 37:374-400

Kunuk Z, Mauro IJ (2010) Qapirangajuq: Inuit knowledge and climate change. In: IsumaTV. http://www.isuma.tv/inuit-knowl edge-and-climate-change. Accessed 2 Jun 2015

Le Quéré C, Andres RJ, Boden T et al (2012) The global carbon budget 1959-2011. Earth System Science Data Discussions 5:1107-1157. doi:10.5194/essdd-5-1107-2012

Leary NA (1999) A framework for benefit-cost analysis of adaptation to climate change and climate variability. Mitig Adapt Strat Glob Change 4:307-318. doi:10.1023/A:1009667706027

Leary N, Conde C, Kulkarni J et al (2008) Climate Change and Vulnerability. Earthscan, London

Leary N, Adejuwon J, Barros V et al (2009) A stitch in time: General lessons from specific cases. In: Leary N, Conde C, Kulkarni $\mathbf{J}$ et al (eds) Climate change and adaptation. Earthscan, London, pp 1-27

Leichenko R, O’Brien K (2008) Environmental change and globalization: double exposures. Oxford University Press, Oxford

Lemelin RH, Wiersma EC, Trapper L et al (2013) A dialogue and reflection on photohistory: engaging indigenous communities in research through visual analysis. Action Research 11:92-107. doi: $10.1177 / 1476750313476310$

Levitus S, Antonov JI, Boyer TP et al (2012) World ocean heat content and thermosteric sea level change (0-2000 m), 1955-2010. Geophys Res Lett 39:L10603. doi:10.1029/2012GL051106

Ling SD (2008) Range expansion of a habitat-modifying species leads to loss of taxonomic diversity: a new and impoverished reef state. Oecologia 156:883-894. doi:10.1007/s00442-008-1043-9

Lukasiewicz A, Pittock J, Finlayson M (2015) Institutional challenges of adopting ecosystem-based adaptation to climate change. Reg Environ Change. doi:10.1007/s10113-015-0765-6

Lynam T, Mathevet R, Etienne M et al (2012) Waypoints on a journey of discovery: mental models in human-environment interactions. Ecol Soc. doi:10.5751/ES-05118-170323

Maccarrone V, Filiciotto F, Buffa G et al (2014) The ICZM Balanced Scorecard: a tool for putting integrated coastal zone management into action. Marine Policy 44:321-334. doi:10.1016/j.marpol. 2013.09.024

MacDonald JP, Harper SL, Willox AC et al (2013) A necessary voice: climate change and lived experiences of youth in Rigolet, Nunatsiavut, Canada. Glob Environ Change 23:360-371. doi:10. 1016/j.gloenvcha.2012.07.010

Mangi SC, Roberts CM, Rodwell LD (2007) Reef fisheries management in Kenya: preliminary approach using the driver-pressurestate-impacts-response (DPSIR) scheme of indicators. Ocean Coast Manag 50:463-480. doi:10.1016/j.ocecoaman.2006.10.003

Marshall NA, Marshall PA, Tamelander J et al (2010) A framework for social adaptation to climate change: Sustaining tropical coastal communitites and industries. IUCN, Gland

McCubbin S, Smit B, Pearce T (2015) Where does climate fit? Vulnerability to climate change in the context of multiple stressors in Funafuti, Tuvalu. Glob Environ Change 30:43-55. doi:10.1016/j.gloenvcha.2014.10.007
McGranahan G, Balk D, Anderson B (2007) The rising tide: assessing the risks of climate change and human settlements in low elevation coastal zones. Environment and Urbanization 19:17-37. doi:10.1177/0956247807076960

McLeod IM, Rummer JL, Clark TD et al (2013) Climate change and the performance of larval coral reef fishes: the interaction between temperature and food availability. Conserv Physiol 1:cot024. doi: $10.1093 /$ conphys/cot024

Mechler R, Nabiul Islam KM (2013) Cost-benefit analysis of disaster risk management and climate adaptation: the case of Bangladesh. In: Guha-Sapir D, Santos I (eds) The economic impacts of natural disasters. Oxford University Press, New York, pp 80-106

Mee L (2012) Between the devil and the deep Blue Sea: the coastal zone in an Era of globalisation. Estuar Coast Shelf Sci 96:1-8. doi:10.1016/j.ecss.2010.02.013

Menzie CA, MacDonell MM, Mumtaz M (2007) A phased approach for assessing combined effects from multiple stressors. Environ Health Perspect 115:807-816

Merino G, Barange M, Blanchard JL et al (2012) Can marine fisheries and aquaculture meet fish demand from a growing human population in a changing climate? Glob Environ Change 22: 795-806. doi:10.1016/j.gloenvcha.2012.03.003

Millenium Ecosystem Assessment (2005) Ecosystems and human well-being. World Resources Institute and Island Press, Washington, D.C.

Mills D, Béné C, Ovie S et al (2011) Vulnerability in African small-scale fishing communities. J Int Dev 23:308-313. doi:10.1002/jid.1638

Moerlein KJ, Carothers C (2012) Total environment of change: Impacts of climate change and social transitions on subsistence fisheries in Northwest Alaska. Ecol Soc. doi:10.5751/ES-04543-170110

Molden D, Frenken K, Barker R et al (2007) Trends in water and agricultural development. In: Molden D (ed) Water for food, water for life : a comprehensive assessment of water management in agriculture. Earthscan, London

Moore M-L, Tjornbo O, Enfors E et al (2014) Studying the complexity of change: toward an analytical framework for understanding deliberate social-ecological transformations. Ecol Soc. doi:10.5751/ES-06966-190454

Mueter FJ, Litzow MA (2008) Sea ice retreat alters the biogeography of the bering sea continental shelf. Ecol Appl 18:309-320. doi:10.1890/07-0564.1

Munaretto S, Siciliano G, Turvani ME (2014) Integrating adaptive governance and participatory multicriteria methods: a framework for climate adaptation governance. Ecol Soc. doi:10.5751/ ES-06381-190274

Munday PL, Jones GP, Pratchett MS, Williams AJ (2008) Climate change and the future for coral reef fishes. Fish Fish 9:261-285. doi:10.1111/j.1467-2979.2008.00281.x

Mustafa D (1998) Structural causes of vulnerability to flood hazard in Pakistan*. Economic Geography 74:289-305. doi:10.1111/j. 1944-8287.1998.tb00117.x

Nalau J, Preston BL, Maloney MC (2015) Is adaptation a local responsibility? Environ Sci Policy 48:89-98. doi:10.1016/j. envsci.2014.12.011

Nay JJ, Abkowitz M, Chu E et al (2014) A review of decision-support models for adaptation to climate change in the context of development. Climate and Development 6:357-367. doi:10. 1080/17565529.2014.912196

Nelson GC, Bennett EM, Berhe AA, et al (2005) Drivers of change in ecosystem condition and services. Ecosystems and human well being (Volume 2: Scenarios), Millenium ecosystem assessment. Island Press, Washington, DC, pp 173-222

Nicholls RJ, Hanson S, Herweijer C, et al (2007) Ranking port cities with high exposure and vulnerability to climate extremes: exposure estimates. Organisation for economic and co-operative development (OECD), Paris, France 
Njock J-C, Westlund L (2010) Migration, resource management and global change: experiences from fishing communities in West and Central Africa. Marine Policy 34:752-760. doi:10.1016/j. marpol.2010.01.020

O’Brien KL (2009) Do values subjectively define the limits to climate change adaptation? In: Adger WN, Lorenzoni I, O'Brien KL (eds) Adapting to Climate Change: Thresholds, Values, Governance. Cambridge University Press, Cambridge, pp 164-180

O'Brien KL, Leichenko RM (2000) Double exposure: assessing the impacts of climate change within the context of economic globalization. Glob Environ Change 10:221-232. doi:10.1016/ S0959-3780(00)00021-2

O'Brien KL, Leichenko RM (2003) Winners and losers in the context of global change. Ann Assoc Am Geogr 93:89-103. doi:10.1111/ 1467-8306.93107

O’Brien KL, Wolf J (2010) A values-based approach to vulnerability and adaptation to climate change. WIREs Clim Chg 1:232-242. doi: $10.1002 /$ wcc. 30

O’Brien KL, Leichenko R, Kelkar U et al (2004) Mapping vulnerability to multiple stressors: climate change and globalization in India. Glob Environ Change 14:303-313. doi:10.1016/ j.gloenvcha.2004.01.001

O'Connor MI, Piehler MF, Leech DM et al (2009) Warming and resource availability shift food web structure and metabolism. PLoS Biol 7:e1000178. doi:10.1371/journal.pbio.1000178

Ommer RE, Team (2007) Coasts under stress: Restructuring and social-ecological health. McGill-Queen's Press, Montreal

Ottersen G, Hjermann DØ, Stenseth NC (2006) Changes in spawning stock structure strengthen the link between climate and recruitment in a heavily fished cod (Gadus morhua) stock. Fish Oceanogr 15:230-243. doi:10.1111/j.1365-2419.2006.00404.x

Paavola J (2008) Livelihoods, vulnerability and adaptation to climate change in Morogoro, Tanzania. Environ Sci Policy 11:642-654. doi:10.1016/j.envsci.2008.06.002

Paul BG, Vogl CR (2011) Impacts of shrimp farming in Bangladesh: challenges and alternatives. Ocean Coast Manag 54:201-211. doi:10.1016/j.ocecoaman.2010.12.001

Pelejero C, Calvo E, Hoegh-Guldberg O (2010) Paleo-perspectives on ocean acidification. Trends Ecol Evol 25:332-344. doi:10.1016/ j.tree.2010.02.002

Perry RI, Ommer RE, Sumaila RU et al (2010) Interactions between changes in marine ecosystems and human communities. In: Barange M, Field J, Harris R et al (eds) Marine ecosystems and global change. Oxford University Press, Oxford, pp 221-252

Perry RI, Ommer RE, Barange $M$ et al (2011) Marine socialecological responses to environmental change and the impacts of globalization. Fish Fish 12:427-450. doi:10.1111/j.1467-2979. 2010.00402.x

Pfeffer WT, Harper JT, O'Neel S (2008) Kinematic constraints on glacier contributions to 21 st-Century sea-level rise. Science 321:1340-1343. doi:10.1126/science.1159099

Pike DA (2014) Forecasting the viability of sea turtle eggs in a warming world. Glob Change Biol 20:7-15. doi:10.1111/gcb.12397

Pinto da Silva P, Kitts A (2006) Collaborative fisheries management in the Northeast US: emerging initiatives and future directions. Marine Policy 30:832-841. doi:10.1016/j.marpol.2006.04.003

Pollock FJ, Lamb JB, Field SN et al (2014) Sediment and turbidity associated with offshore dredging increase coral disease prevalence on nearby reefs. PLoS ONE 9:1-9. doi:10.1371/journal. pone. 0102498

Polovina JJ, Howell EA, Abecassis M (2008) Ocean's least productive waters are expanding. Geophys Res Lett 35:L03618. doi:10. 1029/2007GL031745

Porthin M, Rosqvist T, Perrels A, Molarius R (2013) Multi-criteria decision analysis in adaptation decision-making: a flood case study in Finland. Reg Environ Change 13:1171-1180. doi:10. 1007/s10113-013-0423-9

Raymond CM, Bryan BA, MacDonald DH et al (2009) Mapping community values for natural capital and ecosystem services. Ecol Econ 68:1301-1315. doi:10.1016/j.ecolecon.2008.12.006

Reid MG, Hamilton C, Reid SK et al (2014) Indigenous climate change adaptation planning using a values-focused approach: a case study with the gitga'at nation. Journal of Ethnobiology 34:401-424. doi:10.2993/0278-0771-34.3.401

Richards R, Sanó M, Roiko A et al (2013) Bayesian belief modeling of climate change impacts for informing regional adaptation options. Environ Model Softw 44:113-121. doi:10.1016/j. envsoft.2012.07.008

Rockström J, Steffen W, Noone K, et al (2009a) Planetary boundaries: Exploring the safe operating space for humanity. Ecol Soc 14:2

Rockström J, Steffen W, Noone K et al (2009b) A safe operating space for humanity. Nature 461:472-475. doi:10.1038/461472a

Roiko A, Mangoyana RB, McFallan S et al (2012) Socio-economic trends and climate change adaptation: the case of South East Queensland. Australasian Journal of Environmental Management 19:35-50. doi:10.1080/14486563.2011.646754

Rummer JL, Couturier CS, Stecyk JAW et al (2014) Life on the edge: thermal optima for aerobic scope of equatorial reef fishes are close to current day temperatures. Glob Change Biol 20:1055-1066. doi:10.1111/gcb.12455

Sahin O, Mohamed S, Warnken J, Rahman A (2013) Assessment of sea-level rise adaptation options: multiple-criteria decisionmaking approach involving stakeholders. Structural Survey 31:283-300. doi:10.1108/SS-01-2013-0006

Salter J, Robinson J, Wiek A (2010) Participatory methods of integrated assessment - a review. WIREs Clim Chg 1:697-717. doi: $10.1002 /$ wcc. 73

Scheuer S, Haase D, Meyer V (2011) Exploring multicriteria flood vulnerability by integrating economic, social and ecological dimensions of flood risk and coping capacity: from a starting point view towards an end point view of vulnerability. Nat Hazards 58:731-751. doi:10.1007/s11069-010-9666-7

Schwarz A-M, Béné C, Bennett G et al (2011) Vulnerability and resilience of remote rural communities to shocks and global changes: empirical analysis from Solomon Islands. Glob Environ Change 21:1128-1140. doi:10.1016/j.gloenvcha.2011. 04.011

Scoones I (1998) Sustainable rural livelihoods: A framework for analysis. IDS Discussion Paper 72, University of Sussex, UK

Scoones I (2009) Livelihoods perspectives and rural development. J of Peasant Stud 36:171-196. doi:10.1080/03066150902820503

Sen A (1982) Poverty and famines: An essay on entitlement and deprivation. Clarendon Press; Oxford University Press, Oxford; New York

Sheppard SRJ, Shaw A, Flanders D et al (2011) Future visioning of local climate change: a framework for community engagement and planning with scenarios and visualisation. Futures 43:400-412. doi:10.1016/j.futures.2011.01.009

Shiklomanov IA, Rodda JC (2004) World Water Resources at the Beginning of the Twenty-First Century. UNESCO and Cambridge University Press, Cambridge

Silva JA, Eriksen S, Ombe ZA (2010) Double exposure in Mozambique's Limpopo River Basin. Geogr J 176:6-24. doi:10.1111/j. 1475-4959.2009.00343.x

Small C, Nicholls RJ (2003) A global analysis of human settlement in coastal zones - tags: human settlements coastal ecology. J Coastal Res 19:584-592

Smit B, Wandel J (2006) Adaptation, adaptive capacity and vulnerability. Glob Environ Change 16:282-292. doi:10.1016/j.gloenv cha.2006.03.008 
Smith K (2013) Environmental hazards: Assessing risk and reducing disaster. Sixth, Routledge

Smith JB, Klein RJT, Huq S (2003) Climate change, adaptive capacity and development. Imperial College Press, London

Smith TF, Thomsen DC, Gould S et al (2013) Cumulative pressures on sustainable livelihoods: coastal adaptation in the mekong delta. Sustainability 5:228-241. doi:10.3390/su5010228

Steffen W, Richardson K, Rockström J et al (2015) Planetary boundaries: guiding human development on a changing planet. Science. doi:10.1126/science.1259855

Steneck RS, Graham MH, Bourque BJ et al (2002) Kelp forest ecosystems: biodiversity, stability, resilience and future. Environ Conserv 29:436-459. doi:10.1017/S0376892902000322

Suckall N, Tompkins E, Stringer L (2014) Identifying trade-offs between adaptation, mitigation and development in community responses to climate and socio-economic stresses: evidence from Zanzibar, Tanzania. Applied Geography 46:111-121. doi:10. 1016/j.apgeog.2013.11.005

Swart RJ, Raskin P, Robinson J (2004) The problem of the future: sustainability science and scenario analysis. Global Environ Change A Human Policy Dimens 14:137-146

Syvitski JPM, Kettner A (2011) Sediment flux and the anthropocene. Phil Trans R Soc A 369:957-975. doi:10.1098/rsta.2010.0329

Thomsen DC, Smith TF, Keys N (2012) Adaptation or manipulation? Unpacking climate change response strategies. Ecol Soc. doi:10. 5751/ES-04953-170320

Tomei J, Lucas K, Vanner R (2006) A review of tools and techniques for community. SuScit: citizen science for sustainability, policy studies institute (PSI), the centre for sustainable development (CfSD) at the University of Westminster

Tschakert P (2007) Views from the vulnerable: understanding climatic and other stressors in the Sahel. Glob Environ Change 17:381-396. doi:10.1016/j.gloenvcha.2006.11.008

Tscherning K, Helming K, Krippner B et al (2012) Does research applying the DPSIR framework support decision making? Land Use Policy 29:102-110. doi:10.1016/j.landusepol.2011.05.00

Tuler S, Agyeman J, da Silva PP et al (2008) Assessing vulnerabilities: integrating information about driving forces that affect risks and resilience in fishing communities. Human Ecology Review 15:171-184

Tuler SP, Webler T, Polsky C (2013) A rapid impact and vulnerability assessment approach for commercial fisheries management. Ocean Coast Manag 71:131-140. doi:10.1016/j.ocecoaman. 2012.09.013

Turner BL, Kasperson RE, Matson PA et al (2003) A framework for vulnerability analysis in sustainability science. Proc Natl Acad Sci U S A 100:8074-8079. doi:10.1073/pnas.1231335100

Tyler S, Moench M (2012) A framework for urban climate resilience. Clim Dev 4:311-326. doi:10.1080/17565529.2012.745389
UNDP (2013) 2013 Human development report human development reports. United Nations Development Program

Van den Bergh JCJM (2004) Optimal climate policy is a utopia: from quantitative to qualitative cost-benefit analysis. Ecol Econ 48:385-393. doi:10.1016/j.ecolecon.2003.10.011

Vogel C (1998) Vulnerability and global environmental change. LUCC Newsletter 3:15-19

Walker G (2012) Climate change oppression: media production as the practice of freedom. Consilience J Sustain Dev 9:97-106

Walker B, Holling CS, Carpenter SR, Kinzig A (2004) Resilience, adaptability and transformability in social-ecological systems. Ecology and society 9:5

Watkiss P, Hunt A, Blyth W, Dyszynski J (2014) The use of new economic decision support tools for adaptation assessment: A review of methods and applications, towards guidance on applicability. Clim Change. doi:10.1007/s10584-014-1250-9

Watson R, Zeller D, Pauly D (2014) Primary productivity demands of global fishing fleets. Fish Fish 15:231-241. doi:10.1111/faf. 12013

Watts MJ, Bohle HG (1993) The space of vulnerability: the causal structure of hunger and famine. Prog Hum Geogr 17:43-67. doi: $10.1177 / 030913259301700103$

Wegner G, Pascual U (2011) Cost-benefit analysis in the context of ecosystem services for human well-being: a multidisciplinary critique. Glob Environ Change 21:492-504. doi:10.1016/j. gloenvcha.2010.12.008

West P, Igoe J, Brockington D (2006) Parks and peoples: the social impact of protected areas. Annu Rev Anthropol 35:251-277. doi:10.1146/annurev.anthro.35.081705.123308

Willox AC, Harper SL, Edge VL et al (2013) Storytelling in a digital age: digital storytelling as an emerging narrative method for preserving and promoting indigenous oral wisdom. Qualitative Research 13:127-147. doi:10.1177/1468794112446105

Wise RM, Fazey I, Stafford Smith M et al (2014) Reconceptualising adaptation to climate change as part of pathways of change and response. Glob Environ Change 28:325-336. doi:10.1016/j. gloenvcha.2013.12.002

Worm B, Barbier EB, Beaumont $\mathrm{N}$ et al (2006) Impacts of biodiversity loss on ocean ecosystem services. Science 314:787-790. doi:10.1126/science.1132294

Zou L-L, Wei Y-M (2010) Driving factors for social vulnerability to coastal hazards in Southeast Asia: results from the meta-analysis. Nat Hazards 54:901-929. doi:10.1007/s11069-010-9513-x

Zou S, Xu W, Zhang R et al (2011) Occurrence and distribution of antibiotics in coastal water of the Bohai Bay, China: impacts of river discharge and aquaculture activities. Environ Pollut 159:2913-2920. doi:10.1016/j.envpol.2011.04.037 